\title{
Contrarrevolução permanente, antiliberalismo e anticomunismo: as raízes ideológicas do bonapartismo de Alfredo Buzaid, o jurista ditatorial (1965-74)
}

\author{
Rodolfo Costa Machado ${ }^{1}$
}

\section{Resumo:}

O artigo destaca, entrelidos como as raízes ideológicas do futuro Ministro da Justiça ditatorial Alfredo Buzaid (1969-1974), dois discursos proferidos pelo jurista ainda enquanto professor da Faculdade de Direito da Universidade de São Paulo (FDUSP). Na polêmica travada em 1965 contra biógrafo de Rui Barbosa, mas principalmente em seu discurso de posse de diretor da FDUSP de 1966, resgatam-se as críticas buzaidianas ao liberalismo e ao comunismo, bem como a propositura de uma espécie de terceira via, de cunho cristão, encontrada na democracia social. Salientase aí o entendimento buzaidiano sobre a necessidade de formação dos homens públicos para "o processo de racionalização da democracia", interditado o sufrágio universal. Exposta tal visão antipopular e autocrática, analisa-se o primeiro discurso ministerial de Buzaid, "Rumos Políticos da Revolução Brasileira" (1970), que o consagra como o jurista do bonapartismo e no qual é reposta a tese sobre a "racionalização" da democracia que estaria, então, sendo feita pelo general-ditador Emílio Garrastazu Médici. Apanhando o bonapartismo brasileiro de 1964 como um domínio exercido de modo indireto pelo conjunto da burguesia, resgata-se Buzaid como o jurista oficial de sua fração medicista, pintada por ele como a mantenedora de um estado de justiça anticomunista que conteria e superaria o estado de direito liberal. Buzaid é circunscrito, então, à facção continuísta do bonapartismo, sendo apontado como ideólogo e homem de ação da contrarrevolução permanente, indicando-se os principais nódulos do ideário buzaidiano no marco da Ideologia 64, como as concepções de estado ético, política "científica" e filosofia espiritualista atribuídas pelo ministro da Justiça à ditadura brasileira. Expostos tais vincos regressivos do bonapartismo buzaidiano, sinaliza-se a filiação de Buzaid ao antigo integralismo de Plínio Salgado - como as raízes ideológicas "ocultas" de seu ideário -, motivo da retomada da tese de J. Chasin sobre o integralismo pliniano. Adverte-se, ainda, a necessidade de compreensão da forma pela qual essa matriz integralista do ideário buzaidiano se fundiu e se readequou tardiamente, em plena Guerra Fria, à doutrina de Segurança Nacional e Desenvolvimento da ditadura militar recrudescida. Por último, indica-se o engajamento do ex-ministro

1 Doutorando pela Pontifícia Universidade Católica de São Paulo (PUC-SP)/Visiting Scholar at Columbia University in NYC. E-mail: rod.cmachado@gmail.com. 
Buzaid no "capítulo" brasileiro da Liga Mundial Anticomunista (WACL) e da Confederação Anticomunista Latinoamericana (CAL), que o consagrou como um cold warrior de projeção transnacional.

Palavras-chave: Alfredo Buzaid; antiliberalismo; anticomunismo; bonapartismo 1964 .

\title{
Permanent counterrevolution, anti-liberalism and anti- communism: ideological the roots of Alfredo Buzaid's bonapartism, the dictatorial jurist (1965-74)
}

\begin{abstract}
:
This article highlights, grasped as the ideological roots of the future dictatorial Ministry of Justice Alfredo Buzaid (1969-1974), two speeches delivered by the jurist while being a professor of the Law School of University of Sao Paulo (FDUSP). In controversy stablished in 1965 against Rui Barbosa's biographer, but mostly in his speech of acceptance for the post of Director of FDUSP in 1966, the article resumes Buzaid's critiques against liberalism and communism, as well as his proposition for a sort of a third Christian path found in the social democracy. It is emphasized Buzaid's comprehension about the necessity of the public man's formation for the so-called 'process of rationalization of democracy', interdicting the universal suffrage. Once exposed his antipopular and autocratic conception, the article analyses the first ministerial speech of Buzaid, 'Political Paths of Brazilian Revolution' (1970), which anointed Buzaid as the jurist of the Bonapartism and restated the thesis of the 'rationalization of democracy' by the dictator Emílio Garrastazu Médici. Reading the 1964 Brazilian Bonapartism as an indirect rule of the bourgeoisie, the article aims to understand Buzaid as the official jurist of its Medicist fraction, depicted by him as an anti-communist Justice State that overcame the liberal State of Law. Buzaid is circumscribed as a member of the eternization of Bonapartism, pointing out the jurist as an ideologue and a man of action of the permanent counterrevolution, drawing the Buzaid's ideology in the framework of 64 Ideology, such as its conceptions of an ethical State, a 'scientific' politic and a spiritualist philosophy assigned by the jurist to the Brazilian dictatorship. Exposing the regressive Buzaid's world view, this article signalizes Buzaid's filiation to the old Plinio Salgado's Integralism as the 'hidden' ideological roots of its Bonapartist ideology, bringing some aspects of the J. Chasin's thesis about the Integralism of Salgado, warning about the necessity to comprehend the specific manner through which this integralist matrix of Buzaid's ideology blent and readapted later, during the Cold War, with the National Security and Development doctrine of the Brazilian military
\end{abstract}


dictatorship. At last, the article points out the engagement of Buzaid in the Brazilian "chapter" of the World Anticommunist League (WACL) and the Latin-American Anticommunist Confederation (CAL), which consecrated Buzaid as an international cold warrior.

Key words: Alfredo Buzaid; Antiliberalism; Anticommunist; 1964 Brazilian Bonapartism.

Este artigo destaca, num primeiro momento, dois textos políticos de Alfredo Buzaid elaborados após o golpe de 1964 (de que ele participou): um embate de 1965 contra biógrafo de Rui Barbosa e seu discurso de posse como diretor da Faculdade de Direito da Universidade de São Paulo (FDUSP) em 1966, no qual delineia um "Estudo sobre os rumos da democracia no Brasil". Identificam-se ali as raízes ideológicas que compuseram a matriz do primeiro discurso de Buzaid, de 1970, como ministro da Justiça da ditadura de Emílio Garrastazu Médici (1969-74). Intitulado "Rumos Políticos da Revolução Brasileira", sua primeira alocução ministerial o consagra como $o$ jurista oficial do bonapartismo medicista, repondo as mesmíssimas teses do professor/diretor da FDUSP. Considerando-se o bonapartismo brasileiro como "uma forma de poder autocrático dos proprietários, que não é exercida diretamente pela classe dos capitalistas" - isto é, um “domínio exercido de modo indireto pelo conjunto da burguesia, pelas armas, subjugando, castrando ou atrelando os poderes legislativo e judiciário" (ASSUNÇÃO, 2013, p. 56) -, o bonapartismo buzaidiano, no marco da Ideologia 64 de Segurança Nacional e Desenvolvimento, encarnou e se filiou a sua vertente recrudescida, o medicismo, que buscou a "construção da grande potência pela aliança de crescimento econômico acelerado com terrorismo oficial" (RAGO, 1998, p. 1) ${ }^{2}$.

$\mathrm{Na}$ medida em que se apontam outras alocuções buzaidianas construídas no marco medicista, é possível perceber que as noções regressivas do jurista da ditadura recrudescida apresentaram, além dessas matrizes ideológicas encontradas nos discursos buzaidianos da década de 1960 (em que criticara o liberalismo e o comunismo em nome de uma doutrina social cristã), outras raízes "ocultas" inscritas no ideário de Buzaid. Elas devem ser procuradas antes da guerra fria, em outro sítio: na

2 Sobre o recurso ao estado de natureza bonapartista como vocação da burguesia brasileira, Maria Aparecida de Paula Rago esclarece: "Trata-se de um domínio imposto pela coerção, avesso radicalmente às conquistas democráticas vindas dos 'de baixo'. Desse modo, nossa formação histórica se caracterizou por uma dominação autocrática pendular: num polo, o terrorismo de classe aberto, a forma bonapartista de dominação; no outro, a autocracia burguesa legalizada, institucionalizada, que expressa a democracia restrita dos proprietários, a transpirar seus interesses egoísticos, particularistas e exclusivistas" (RAGO, 2008, p. 138). 
filiação de Buzaid ao integralismo de Plínio Salgado nas primeiras décadas do século XX, motivo do resgate de algumas considerações da tese de J. Chasin sobre os principais nódulos ideológicos do integralismo pliniano. A dificuldade advertida, assim, reside em explicar o modo peculiar de articulação e reapropriação feita pelo ministro da Justiça da ditadura Médici, no marco da doutrina de Segurança Nacional e Desenvolvimento que cogestou uma ditadura do grande capital monopolista, daquela regressividade pliniana da década de 1930 que encarnara uma crítica ruralista e romântica ao capitalismo. Sem sugerir que houve uma reapropriação mecânica do velho ideário integralista pliniano pelo ideólogo bonapartista da guerra fria, porém, observa-se que o chefe do Sigma nunca deixou de configurar a matriz "oculta" do bonapartismo buzaidiano.

\section{Buzaid na FDUSP: gestando o ovo da serpente}

Buzaid nasceu em 1914 em Jaboticabal, interior paulista, onde se vinculou, ainda no colégio São Luís, ao integralismo local. Como graduando da FDUSP no início da década de 1930, formou o grupo de estudantes, estrelado por Miguel Reale, que se filiou ao chefe Plínio Salgado e o ajudou a estruturar o movimento integralista. Na década de 1950, Buzaid iniciou sua carreira acadêmica como teórico e professor no campo do processo civil, sendo um dos criadores, sob o signo do italiano Enrico Tulio Liebman (exilado do fascismo), da chamada "Escola Processual de São Paulo”.

O que interessa ressaltar aqui, todavia, é o momento do pré-golpe de 1964. Mais especificamente, a participação de Buzaid - (na) e da FDUSP - na conspiração contra o presidente trabalhista João Goulart. Assinale-se apenas que a FDUSP, na figura de eminentes professores como Miguel Reale, Luís Antonio da Gama e Silva, o próprio Buzaid, entre outros, integrou a conspiração contra Goulart. Buzaid, mais especificamente, integrou o Conselho Orientador do Instituto de Pesquisas Econômicas e Sociais (Ipês), o think tank empresarial-militar que nucleou a conspiração entre 1962-6433. Reale e Gama e Silva também foram ativos líderes ipesianos. No marco conspiratório do QG jurídico do golpe de 1964, a FDUSP animada por Buzaid e Reale criou um curso de especialização, em fevereiro de 1962, intitulado "Marxismo e cristianismo". Com uma ligeira modificação - o acréscimo do subtítulo "O problema do ateísmo" -, o ministro da Justiça ditatorial Buzaid reproduziria futuramente, em discurso de 1970, o aprendizado do referido curso inaugurado na FDUSP.

3 Buzaid ligou-se ao grupo empresarial Fuad Lutfalla (S/A Fiação e Tecelagem, Fazenda Boa Vista S/A Agrícola e Pecuária e Lumaver S/A Empreendimentos) e a Paulo Salim Maluf (DREIFUSS, 1981: 541). 
Ainda no marco ipesiano da conspiração e preparo do golpe de 1964, a FDUSP albergou, em janeiro de 1963, o Congresso Brasileiro para a Definição das Reformas de Base, resposta/formulação dos juristas das classes proprietárias sediciosas que já vislumbrava um cenário político pós-Goulart. As propostas apresentadas na FDUSP foram condensadas na publicação "Reformas de base. Posição do Ipês"4. Vitorioso o golpe de classe e de estado de 1964, a FDUSP aportaria, enfim, a matriz e a expertise legiferantes da ditadura militar em sua fase recrudescida, com Gama e Silva e Buzaid atuando, respectivamente, como ministros da Justiça dos ditadores Artur da Costa e Silva e Médici5.

Sem se aprofundar nisso, no entanto, o que interessa aqui é reconstituir parcela da conferência feita por Buzaid na FDUSP, um ano após o golpe de 1964, inferindo-se daí as raízes ideológicas do futuro bonapartismo buzaidiano. Nessa palestra, o jurista mostra a que veio no cenário jurídico pró-ditadura militar. Sua conferência intitulada Rui e a questão social atacava o livro Rui: o homem e o mito, de Raimundo Magalhães Jr., contra o qual estruturou sua fala de combate anticomunista. Serão destacadas dela as principais raízes ideológicas que Buzaid desenvolveria alguns anos mais tarde, de 1969 a 1974, enquanto ministro da Justiça do ditador Médici. "Atacar” Rui, na dicção buzaidiana, seria uma tática subversiva do pré-1964 intentada por Magalhães Jr., cujo livro instilaria "veneno de ideias" com o objetivo político de "destruir os valores permanentes da tradição cultural e religiosa de um povo" (BUZAID, 1983, p. 1).

Portando-se como como um cruzado cristão-ocidental, com a vitória do golpe militar de 1964, Buzaid qualificava o livro em questão como um produto de época, escrito entre março de 1962 e 1964, "justamente no período em que os agitadores buscavam aniquilar a estrutura social e política do país" (BUZAID, 1983, p. 2). O alegado "ataque" a Rui era entrelido por Buzaid como ato subversivo para "escachar o homem" que "representou a vocação cristã da nacionalidade, ajudou a fundar a República e consolidou o estado brasileiro na exegese construtiva de sua Lei fundamental" (BUZAID, 1983, p. 2). Uma das críticas feita por Magalhães Jr. que forçou a "resposta" do polemista Buzaid consistiu no fato de Rui ter falhado como "intérprete das aspirações populares dos trabalhadores"; desatento à questão social, teria dado de ombro "ao operariado brasileiro, só cuidando dos imigrantes" (BUZAID, 1983, p. 5). Buzaid, refutando a crítica a Rui, defende a posição deste quanto à abolição da escravatura: dever-se-ia, via legislação, "a) dar trabalho livre

4 Sobre o Ipês, cf. DREIFUSS (1981); cf. "As Arcadas e o Ipês na conspiração de classe" (MACHADO, 2015).

5 Sobre o "Fechamento ditatorial e ipesianos da FDUSP no poder: Gama e Silva e Buzaid", cf. Machado (2015). 
ao ex-escravo; b) recusar ao liberto, em qualquer tempo, a vagabundagem" (BUZAID, 1983, p. 10). Buzaid também aplaude o projeto do baiano de instituir um salário mínimo aos libertos, quando "as legislações dos povos civilizados ainda atribuíam valor quase místico à autonomia da vontade individual na formação do contrato de trabalho" (BUZAID, 1983, p. 10). Nesse quesito, segundo Buzaid, Rui esteve à frente do liberalismo europeu, avesso à "fixação de salário" (BUZAID, 1983, p. 10).

Quanto à advertida omissão de Rui frente às referidas greves operárias e às subsequentes "demissões, prisões, espancamentos e assassinatos de líderes operários pela Polícia” (BUZAID, 1983, p. 12), Buzaid relembra, à época de um Brasil ditatorial cuja Lei de Greve de 1964 criminalizou o direito trabalhista, que "não basta, na verdade, que surja uma greve. É necessário que seja juridicamente lícita e moralmente aconselhável, porque a experiência nos mostra que muitas delas não passam de obra de agitadores empenhados em promover a subversão social” (BUZAID, 1983, p. 14). Versando sobre greves no mundo do trabalho, Buzaid expressa seu anticomunismo em confronto com Magalhães Jr:

Rui seria grande aos olhos de seu crítico, se fosse às portas das fábricas incentivar greves, provocar desordens e preparar a revolução social. Aí, sim, ele revelaria a sua qualidade de líder intérprete das reivindicações das massas. Mas, como Rui não tinha vocação de agitador comunista, lança-lhe ao rosto a tacha de indiferente aos problemas dos trabalhadores. (BUZAID, 1983, p. 14)

Buzaid conclui que Magalhães Jr. buscava envenenar a juventude ao dizer que "Rui se alheara ao drama dos trabalhadores", incorrendo no erro de apontar tão só o que o biografado "deixou de fazer a benefício dos trabalhadores, sem realçar, no entanto, o que realizou a favor do Brasil" (BUZAID, 1983, p. 15), esquecendo, enfim, a ação político-legislativa do baiano, preferindo o crítico ver seu biografado "não no Senado, revendo o Código Civil, nem em Haia, legislando para o universo, mas defendendo umas poucas greves sem qualquer significação, surgidas esporadicamente antes que houvesse no Brasil a chamada questão social" (BUZAID, 1983, p. 20). Buzaid elogia a profundidade de Rui na campanha civilista e sua candidatura "à suprema magistratura da nação", fato de profunda influência "na história das ideias democráticas no Brasil" e no "plano da reforma constitucional", construindo "as bases de uma nova política objetiva" (BUZAID, 1983, p. 22), "uma das primeiras vozes que se levantaram no Brasil para justificar a intervenção do estado no domínio das relações econômicas" (BUZAID, 1983, p. 25).

O Rui resgatado por Buzaid, então, teria integrado um "movimento de renovação de ideias tendentes a humanizar as relações entre o capital e 
o trabalho", apoiando a "intervenção do estado no domínio dos contratos, a fim de evitar que a liberdade sacrifique a dignidade da criatura" (BUZAID, 1983, p. 28). Buzaid elogia Rui por ser "uma reação à escola liberal, que ainda domina a economia no derradeiro quartel do século XIX” (BUZAID, 1983, p. 28). Rui teria se conscientizado sobre a questão social (embora Buzaid tenha retoricamente negado sua existência) depois da eclosão da I Guerra Mundial. Rui aplaudiu no socialismo suas qualidades "de são, de benévolo, de confraternal, de pacificador" e, ao adotar "o Código de Malines do Cardeal Mercier" e a noção de que "a concepção individualista dos direitos humanos cede lugar aos direitos sociais" (BUZAID, 1983, p. 35), teria aderido "ao socialismo cristão" e sua democracia social.

Nesse vinco cristão, antepondo ao trato da questão social "alguns princípios de filosofia política" (BUZAID, 1983, p. 36), a "solução" encontrada por Rui - na apropriação ideal buzaidiana de 1965 - foi a adoção de uma nova categoria jurídica: o direito social. Instrumento de mediação "harmonizadora" entre o capital e o trabalho assalariado, o direito social reconheceria a necessidade de "inclusão de normas de direito econômico nas constituições políticas modernas", bem como da "disciplina jurídica das relações entre o capital e o trabalho” (BUZAID, 1983, p. 38). Décadas antes dos europeus, Rui já ensinava que "a concepção individualista dos direitos humanos tem evolvido rapidamente, com os tremendos sucessos deste século, para uma transformação incomensurável das noções jurídicas do individualismo restringidas agora por uma extensão, cada vez maior, dos direitos sociais" (BARBOSA apud BUZAID, 1983, p. 36). Buzaid lembra que Rui se atentou ao fato de que "as nossas constituições têm ainda por normas as declarações de direitos consagrados no século dezoito”. Na apropriação de Rui feita por Buzaid, essas “cartas imortais" já não corresponderiam "exatamente à consciência jurídica do universo", de modo que sua "inflexibilidade individualista", mas não imutável, "alguma coisa tem de ceder (...) ao sopro de socialização que agita o mundo" (BUZAID, 1983, p. 37). Como resposta a isso, Buzaid aponta que Rui optou pelo socialismo cristão do cardeal Mercier, a marca determinante do ideário do baiano, de acordo com o jurista: "não hesitou Rui em filiar-se à democracia social, tal como preconizara o cardeal Mercier, 'essa democracia ampla, serena, leal e, numa palavra, cristã'” (BUZAID, 1983, p. 33). A democracia cristã de Rui "quer assentar a felicidade da classe obreira não na ruína das outras classes, mas na reparação dos agravos que ela até agora tem curtido" (BUZAID, 1983, p. 38), "sem querer o socialismo devastador, que, na linguagem do egrégio prelado belga, rebaixa a questão social a uma luta de apetites, e intenta dar-lhe por solução o que não podia deixar de exacerbá-lo: o antagonismo 
de classe" (BUZAID, 1983, p. 39). O socialismo cristão perfilhado por Rui, na leitura buzaidiana, seria profundamente anticomunista:

Socialismo cristão, socialismo humano, socialismo inspirado na ideia de justiça. Socialismo que não odeia, não persegue e não mata. Socialismo que ampara os economicamente fracos, elimina desigualdades contrastantes e compõe conflitos de interesses não pela lei da força, mas pela força da lei. Socialismo que respeita as liberdades individuais, repudia o partido único e abjura quaisquer formas de ditadura, nomeadamente a ditadura do proletariado, porque esta implanta a violência em lugar da ordem, oprime a criatura humana, destruindo-lhe o espírito criador e semeia a violência organizada justamente onde devia promover o congraçamento das classes. (BUZAID, 1983, pp. 39-40)

Nota-se, por fim, que o anticomunismo de Buzaid na releitura que fez de Rui, destacado este como reação ao liberalismo oitocentista, compôs não somente a polêmica do jurista paulista contra o biógrafo do baiano. Anticomunismo e antiliberalismo, como se verá, entrecruzaram-se e compuseram a tessitura ideológica da visão autocrática de mundo buzaidiana. Um ano depois dessa polêmica sobre Rui, ao assumir o cargo de diretor da FDUSP em 1966, Buzaid exporia novamente as raízes ideológicas autocráticas daquilo que viria a matrizar e estruturar, alguns anos depois, o arcabouço teórico de seus discursos oficiais como futuro ministro da Justiça de Médici (1969-74). Por isso, salientar-se-ão os principais nódulos de seu ideário autocrático explicitados em 1966 e que reaparecerão na ideologia oficial do bonapartismo buzaidiano.

\section{A "missão" da FDUSP na ditadura militar: com a palavra, herr diretor}

No início do discurso de posse de diretor da FDUSP em 1966, intitulado A missão da Faculdade de Direito na conjuntura política atual: estudo sobre os rumos da democracia no Brasil, Buzaid assinala, exercitando sua vocação espiritualista, que o programa da Faculdade "é manter uma tradição de cultura, de civismo e de renovação de ideias, em uma palavra, o seu fadário é conquistar o futuro sem destruir as glórias do passado" (BUZAID, 1968, p. 73). A FDUSP, na alocução do herr diretor, não apresentaria como missão precípua a formação de "profissionais para o exercício da advocacia", mas teria sim "uma vocação messiânica" (BUZAID, 1968, p. 73), apresentando "a primeira floração de uma plêiade de juristas, políticos, legisladores e literatos, que despontam no alvorecer da nacionalidade. Daí em diante, numa sucessão nunca interrompida”, a Faculdade traçaria "os destinos da Pátria na obra de seus filhos” (BUZAID, 
1968, p. 74) ${ }^{6}$. As Arcadas do Direito paulista, pois, como construtora, sob o Império escravagista, da nação. "Se tocasse a esta Casa apenas o papel de formar bacharéis em direito, seria um curso profissional", "seria uma escola, não um templo. Teria professores, não sacerdotes. Viveria em contato, com os códigos e as leis, mas estaria divorciada do mundo, dos seus dramas, das suas crises e das ideias que o agitam" (BUZAID, 1968, p. 74).

O que interessa, por ora, é flagrar que o diretor da FDUSP Buzaid delineou as linhagens antiliberais e anticomunistas de seu autocratismo antipopular que, quatro anos mais tarde, seriam desenvolvidas por ele enquanto ideólogo oficial do bonapartismo. Em primeiro lugar, o "conceito de fato político" inscreveu-se no centro do ideário buzaidiano exposto em 1966. Amparado no filósofo francês Michel Debrun, Buzaid assinala que "todos os problemas que interessam à permanente renovação dos espíritos, com serem jurídicos, não deixam de ser políticos”, propondo "uma tomada de consciência da dimensão política e das relações entre a vida política e a vida social total” (BUZAID, 1968, p. 75). Nessa operação politicista, que subordina toda a sociabilidade à sua dimensão política, Buzaid recolhe a ideia democrática como $o$ fato político mais importante da humanidade. Da primeira experiência democrática da Grécia Antiga, Buzaid aponta os debates sobre formas de governo na Política de Aristóteles em que "a democracia degenera em demagogia; a aristocracia, em oligarquias; e a monarquia, em tirania”, salientando o conceito de igualdade em questão: "identidade entre cidadão e membro ativo do estado"; "iguais em não serem escravos, julgam-se iguais em tudo o resto" (BUZAID, 1968, p. 78).

O herr diretor destacou, em 1966, a lembrança da Oração fúnebre atribuída a Péricles por Tucídides, ressaltando que "a grandeza de Atenas provém de suas leis e de seus costumes; foram eles que criaram o heroísmo dos guerreiros". Para Péricles (referindo-se a Atenas), "temos uma Constituição que não se modelou em nenhuma outra, mas que é, antes, um modelo para outras" (PÉRICLES in TUCÍDIDES apud BUZAID, 1968, p. 79). Como se verá, Buzaid usaria exatamente esta frase para envernizar doutrinariamente a ditadura Médici. Enaltecendo a sabedoria política grega, sem criticar a escravidão antiga que lhe servira de base real, Buzaid passa a analisar o advento da democracia moderna ao situar o contratualismo como $o$ apanágio dessa segunda forma histórica da ideia democrática. Buzaid enuncia que a ideia de democracia se reveste "de diferentes formas, que lhe qualificam a estrutura do governo, o sistema de

${ }^{6} \mathrm{O}$ arguto jornalista Carlos Castello Branco, Castellinho, anotara "a vocação autocrática dos juristas que, depois de 1930, assinalaram a presença de São Paulo em matéria institucional (Vicente Rao, Gama e Silva e Alfredo Buzaid)" (CASTELLO BRANCO, 1987, p. 2). 
funcionamento e as relações entre indivíduos e estado" (BUZAID, 1968, p. 85), destacando três vertentes democráticas: "algumas vezes a democracia é identificada com o individualismo liberal; outras vezes, com o socialismo cristão; e não raro até com o marxismo, à maneira do que passa nas chamadas “democracias populares"' (BUZAID, 1968, p. 85).

Não sendo a democracia um "conceito apriorístico oriundo de conjecturas especulativas", apanhando-a como "fato cultural", Buzaid perfilha o método analítico de Burdeau, para quem "o conhecimento dessa realidade, que constitui objeto da filosofia política, não deve transportar o observador para um mundo de meras abstrações; procura, ao contrário, pô-lo em contato com os dados da experiência" (BURDEAU apud BUZAID, 1968). Buzaid indica a necessidade analítica de "verificar as diferenças entre os vários sistemas democráticos, assinalando neles o que há de variável ou permanente, de transitório ou imperecível, de precário ou consistente". Em resumo, o ideário buzaidiano propõe "descobrir em que medida a democracia mudou no decurso de sua evolução e até que ponto pode ser alterada sem sacrifício de seus caracteres essenciais" (BUZAID, 1968, p. 83).

Ao retomar a "variante" da ideia democrática, encarnada na modernidade, Buzaid aduz que "a primeira experiência teve lugar sob a forma do liberalismo político" (BUZAID, 1968, p. 83), cujos teóricos consagrados, Locke, Rousseau e Montesquieu, estabeleceram os "postulados da democracia, o governo do povo pela vontade da maioria, assegurados os direitos fundamentais da liberdade e da igualdade dos cidadãos" (BUZAID, 1968, p. 83). Porém, a crítica buzaidiana ao liberalismo acusa que "a doutrina desses autores sublima a liberdade, elevando-a até o paroxismo místico. A liberdade foi, portanto, como assevera Cabral de Moncada, a primeira grande paixão da democracia" (BUZAID, 1968, p. 85). A segunda ideia democrática ou a segunda paixão teria sido a igualdade, capaz de fanatizar, pelas mãos comunistas, a classe trabalhadora para a revolução social. A partir do capitalismo industrial do século XIX, da concentração de riquezas e da exploração das massas "por um patronato cruel", malogrou-se a democracia liberal burguesa. Com o advento da correlata questão social, o sufrágio universal da democracia liberal "no plano político era inoperante para enfrentar a poderosa organização capitalista da burguesia"; "no plano econômico, deixava o trabalhador exposto às especulações da lei da oferta e da procura, que transforma o trabalho em mercadoria" (BUZAID, 1968, p. 85). No plano religioso, "laicizou-[se] o estado, separando-o da Igreja e não cuidando da parte espiritual do homem" (BUZAID, 1968, p. 85). Eis, assim, a crítica espiritualista de Buzaid ao materialismo da burguesia europeia 
revolucionária que, transformando o medievo, teria aberto as portas da insurreição operária comunista.

O surto industrialista, a formação da burguesia oriunda do terceiro estado, a propaganda de uma consciência pragmática, utilitarista e, por que não dizer, quase materialista, ávida de lucros e prazeres, a redução dos salários, o desemprego e o excesso de horas de trabalho. (BUZAID, 1968, p. 85)

Da crítica buzaidiana à burguesia materialista se alcançaria a crítica do materialismo comunista. A primeira "concorreu para criar as condições econômicas e sociais que possibilitaram o lançamento do Manifesto comunista de 1848, a publicação da encíclica Rerum novarum e o triunfo da Revolução Russa de 1917" (BUZAID, 1968, p. 86). Buzaid, assim, abraça a tese da democracia liberal perempta elaborada por Georges Burdeau jurista ideólogo da República nazicolaboracionista de Vichy: "é provável que sua fórmula (da democracia clássica) esteja hoje perempta”. Contra a suposta "ausência de qualquer intervenção do estado" inerente à democracia liberal, "o estado, que inicialmente era não intervencionista, passa a regular as relações entre o capital e o trabalho, garante aos operários condições de subsistência, admite o direito de greve e institui o seguro social" (BUZAID, 1968, p. 86).

Em 1917, porém, surge um novo regime político "batizado com o nome de democracia popular, "substancialmente diverso da democracia clássica” (BUZAID, 1968, p. 86). Nessa "vertente” da ideia democrática, a igualdade "foi elevada nas democracias populares à eminência de outra paixão da democracia”. Fixando o impacto enorme dos eventos ocorridos na Rússia de 1917, "que ensaiou a maior revolução dos tempos atuais”, o jurista sugere que os marxistas leninistas aproveitaram-se do ressentimento das massas diante da "desigualdade entre os homens, gerada por condições econômico-sociais", com o fito de erigir "a igualdade em palavra mágica capaz de fanatizá-las" (BUZAID, 1968, p. 75). “O complexo de ressentimento foi habilmente explorado pela propaganda socialista, que julgou, através da promessa de igualdade, poder libertar as massas, que contemplam angustiadas o contraste entre a sua miséria econômica e a riqueza dos poderosos" (BUZAID, 1968, p. 75).

A revolução francesa de 1789 ecoaria assim, perigosamente, na revolução soviética de 1917. "A igualdade, que os teóricos da Revolução Francesa põem ao lado da liberdade e da fraternidade como a trilogia do mais puro dos ideais, já hoje é fonte de ódio e de vingança”, sinalizando-se que "a rebelião das massas engendrou uma massa de rebeliões" (BUZAID, 1968, p. 88). As democracias populares "perfilham o marxismo como sua filosofia, sua organização política e sua estrutura econômica”, anunciando o marxismo "como a ideologia dos trabalhadores no seu esforço de libertação" (BUZAID, 1968, p. 88). Buzaid aponta que "o marxismo, no 
entender de seu fundador e dos seus sequazes, não é, portanto, apenas uma mensagem ao proletariado, incitando-o a sublevar contra a burguesia e a abater o sistema capitalista" (BUZAID, 1968, p. 88), mas sim:

Aspira a ser uma nova concepção do homem, uma nova filosofia da vida, uma nova economia política, uma construção definitiva para a futura sociedade do mundo, sem luta de classes, sem propriedade privada, sem exploração do proletariado pela burguesia. (BUZAID, 1968, p. 88)

Buzaid analisa - de modo vulgar, é verdade, mas que não deixa de sinalizar para o que importa - os dois principais filósofos que influenciaram a formação do pensamento marxiano: "sob o aspecto filosófico, Marx se filia a Hegel e a Feuerbach. Do primeiro herdou o método dialético; do segundo, o materialismo. Marx não os segue, porém, como discípulo fiel; supera-os, construindo uma doutrina nova e original" (BUZAID, 1968, p. 88). Se o "método" dialético de Hegel, igualmente vulgarizado em Buzaid, influenciaria Marx, foi Feuerbach, segundo o jurista brasileiro, quem abriu ao revolucionário alemão "a perspectiva do ser real, vivo e concreto" (BUZAID, 1968, p. 88). "Marx adere ao naturalismo, ou mais propriamente ao materialismo de Feuerbach, mas não se contenta com a fundamentação dada pelo filósofo”, no que explicaria, na vulgarização buzaidiana, "segundo o método dialético, a matéria, os antagonismos gerados pelo regime de produção", o lócus encontrado como "o significado real para a vida humana" (BUZAID, 1968, p. 90). "Com esta construção de Marx, bem se vê que ele sobre-excede Feuerbach e Hegel”, "ao afirmar que Hegel crê num dinamismo, que não é real; Feuerbach crê num real, que não é dinâmico” (BUZAID, 1968, p. 90). A conclusão buzaidiana, não de todo equivocada, indica que "Marx chega assim ao ateísmo", reconhecendo que, antes de Marx, Saint-Simon, Fourier, Owen e outros "reconheceram o antagonismo de classes e a ação dos elementos dissolventes na própria sociedade reinante" (BUZAID, 1968, p. 91).

Na sequência, citando o Manifesto comunista de Marx e Engels, sumaria o jurista que, pelo panfleto político de 1848, “o fito imediato dos comunistas é: a) - constituir os proletários em classe; b) - derruir a supremacia burguesa; c) - conquistar o poder político pelo proletariado" (BUZAID, 1968, p. 92). Falando do "estado do proletariado, em que este exerce o poder, a fim de construir uma sociedade sem classes, ou em outras palavras, em que serão suprimidas todas as classes", o jurista acerta ao dizer que "quando Marx alude, no manifesto comunista, à conquista da democracia, não quer significar o triunfo deste regime como o entenderam os publicistas do século XIX. A expressão é entendida como equivalente de proletariado" (BUZAID, 1968, p. 93). Buzaid ainda indica que, na Nova Gazeta Renana: Órgão da Democracia, aos 7 de novembro de 1848, Marx 
teria aconselhado, finalmente, o emprego do terrorismo como método de ação revolucionária, ao escrever: 'Ai dos vencidos! Os massacres das jornadas de junho e de outubro persuadirão os povos de que há um único meio: o terrorismo revolucionário"” (MARX apud BUZAID, 1968, p. 93).

Ao insistir na distinção de Marx dos marxismos, Buzaid busca criticar o pensamento marxista em "alguns de seus aspectos fundamentais", tomando "em consideração, como dados da vida real, a experiência realizada na Rússia Soviética e nas chamadas democracias populares" (BUZAID, 1968, p. 94). Abordando Lênin, aduz que, para se alcançar uma nova civilização que liberte o homem da ignomínia e dos horrores da exploração capitalista, sustentam os marxistas-leninistas que "é indispensável criar um tipo de estado que prossiga na luta até a implantação da sociedade comunista” (LÊNIN apud BUZAID, 1968, p. 94). Ademais, "para Marx e Engels, escreve Burdeau, 'o estado não é nem a nação organizada pelos publicistas liberais, nem um efeito da dissociação das funções como creem os sociólogos", mas "um produto do antagonismo das classes"”. Buzaid critica, enfim, a Constituição soviética e a inexistência de liberdades individuais e do direito de criticar na União Soviética, bem como "a estatização das doutrinas marxistas" que permitira a eleição de um paradigma oficial que "tolhe o espírito criador e embota a sensibilidade política”, fazendo a ditadura do partido único desaparecer com "qualquer oposição de tendência quanto ao sistema político desejável” (BUZAID, 1968, pp. 95-6).

Em suma, nem a democracia política liberal, nem a democracia popular marxista-leninista. Para Buzaid, "entre os extremos do liberalismo político do século XIX e das ditaduras do proletariado do século XX nasce um novo regime, conhecido por democracia social". Pontua o jurista que diante da ideia "marxista, que considera a luta de classes como a causa primordial da exploração dos trabalhadores, verificaram os publicistas, filósofos e pensadores que, não sendo possível salvar a liberdade em sua pureza originária, era necessário salvar pelo menos a democracia” (BUZAID, 1968, p. 97). Salvá-la da perempta democracia liberal e da massa de rebeliões por igualdade da corrente marxista-leninista e suas democracias populares, convencendo-se, como dissera Rui, que “'a democracia evolve, de sua forma originária eminentemente política, como apregoara o liberalismo da Revolução Francesa, para uma nova forma social, reclamada pelas necessidades inelutáveis dos tempos modernos” (BARBOSA apud BUZAID, 1968, p. 97).

A democracia social evolve da forma precedente, todavia, de modo a salvar seu núcleo básico: a livre empresa capitalista protegida pelo estado. A democracia social, pois, não significa "uma ruptura com a democracia política, mas a sua natural continuação, o aperfeiçoamento de 
suas instituições tradicionais" (BUZAID, 1968, p. 97). "Diversamente das constituições do século XIX, elaboradas sob a inspiração das ideias do liberalismo, as constituições europeias do século XX reconhecem e proclamam solenemente os direitos sociais" (BUZAID, 1968, p. 99). "Expressão do bem-estar para todos, a democracia social é um produto da livre empresa, da iniciativa individual, da concorrência. Só que, sobrevindo uma crise, logo os olhos se voltam para o estado" (BURDEAU apud BUZAID, 1968, p. 99). "Esta nova categoria de direitos, denominados direitos sociais", nas palavras de Buzaid, "resulta da nova posição do homem, considerado não mais individualmente um em face do outro, mas como titular de direitos em face da sociedade, que tem por seu turno deveres para com os membros que a integram" (BUZAID, 1968, p. 99). Democracia social, então, como a terceira expressão da ideia democrática na história, "terceira via" entre dois extremos: a democracia liberal perempta e a demonizada democracia popular marxista-leninista. Exemplos da democracia social após a II Guerra Mundial seriam o "esforço dos governos no sentido de assegurar possibilidades iguais, melhoria do padrão de vida, proteção aos trabalhadores contra os riscos do desemprego, assistência à infância e amparo à velhice" (BUZAID, 1968, p. 99).

\footnotetext{
E tudo isso foi possível atingir sem alterar substancialmente a estrutura do estado, isto é, por um lento processo evolutivo que afasta o surto revolucionário violento preconizado pelas esquerdas. Mantém-se a ordem social fundada sobre a ideia de livre empresa, de iniciativa individual e de espírito de competição. (BUZAID, 1968, p. 99)
}

A democracia social nucleada pela livre empresa e encarnada no estado teria por função servir de barragem anticomunista e contrarrevolucionária às esquerdas. "Assim, o bem-estar, que a democracia social promove, só pode realizar-se pela ação do governo”, configurando "uma filosofia do estado construída com base na dignidade da pessoa humana e nas exigências dos complexos problemas dos tempos atuais". Nas palavras do jurista paulista, "o mérito da democracia social foi o de manter as ideias de liberdade, de igualdade e fraternidade, afastandose do otimismo dos ideólogos que creram que a mínima intervenção do estado e a separação dos poderes fossem capazes de estabelecer o equilíbrio nas relações sociais" (BUZAID, 1968, p. 100). A tese de Buzaid, como crítico do liberalismo, seria a de que "os pensadores do liberalismo político não viram que o advento da burguesia haveria de quebrar a unidade do sistema, provocando a formação do operariado que levantaria a bandeira de uma nova revolução contra os privilégios da classe dominante" (BUZAID, 1968, p. 100). Com a unidade do sistema quebrada pela emergência da burguesia e pela subsequente ameaça proletário- 
comunista, a democracia social seria a panaceia legiferante buzaidiana: "vencendo a luta de classes, a democracia social procurou compor as pretensões da classe burguesa e da classe operária num supremo esforço de obter, através de processo pacífico, uma legislação apta a conter os desregramentos, as ambições desmedidas e os abusos da "primeira e de assegurar à segunda medidas de proteção, de assistência e de elevação" (BUZAID, 1968, p. 100). Vencer a luta de classes seria o alvo da democracia social, caracterizando-se como a vantagem que "o marxismo não viu ou não quis ver”, pois ao incitar "as massas à revolução social, acabou por entregá-las às mãos de um partido único, erigindo em quarta classe que substitui os privilégios do dinheiro pelos privilégios do poder" (BUZAID, 1968, p. 100).

Buzaid retoma a teorização sobre as três "vertentes" políticoculturais da ideia democrática: os "três momentos históricos que correspondem a três experiências universais", a democracia políticoliberal, a popular-marxista e a social, explicitando sua concepção espiritualista da história. "Cada uma delas apregoa que realiza o ideal da autêntica democracia", "mas a democracia apresenta, em cada uma dessas expressões políticas, caráter diverso, sujeito às contingências dos novos dados que a história da humanidade revela na dialética das forças do espírito e das condições sociais" (BUZAID, 1968, p. 101). Eis, portanto, para Buzaid, "o grave problema da essência da democracia": particularizar seu modo de existência. Dentre os pensadores, seriam os juristas notadamente Kelsen e Schmitt - os que "procuram extremar o conceito de democracia, particularizando-lhe a essência" (BUZAID, 1968, p. 103).

Ao abordar os três elementos da democracia como povo, liberdade e igualdade, Buzaid resgata Kelsen, para quem democracia significaria "identidade de dirigentes e dirigidos, do sujeito e do objeto do poder do estado e governo do povo pelo povo", questionando: mas "então que é o povo?” (BUZAID, 1968, p. 103). Se este, fragmentado nacional, religiosa e economicamente, "representa, segundo um critério sociológico, antes um conglomerado de grupo do que uma massa composta de natureza homogênea", novamente ancorado em Burdeau, Buzaid critica a concepção dominante nos séculos XVIII e XIX que identificava democracia com a ideia de soberania popular. Tal identificação seria mais "um dogma do liberalismo político, que a nosso ver tem apenas valor genérico, porque enuncia a fonte do poder, mas não a maneira de exercê-lo" (BUZAID, 1968, p. 104). Mas o que preocupa a moderna doutrina é a particularização do "modo como se exprime a vontade popular, tanto mais que, como observa Burdeau, 'se é sempre o povo que governa, não é sempre o mesmo povo" (BUZAID, 1968, p. 104). Assim, correlacionando um crítico conservador do sufrágio universal, Buzaid afirma que “o povo se agita bem 
menos pelos mais capazes de governar" (TOCQUEVILLE apud BUZAID, 1968, p. 104), concluindo com Ferneuil (Les principes de 1789):

$\mathrm{O}$ estado democrático (...) convoca o governo dos melhores. $\mathrm{O}$ futuro do governo popular está subordinado a esta condição expressa que as massas democráticas adquirirão, pela educação e pela prática das instituições livres, a clarividência necessária para discernir entre suas preferências os elementos mais sãos, os mais vivazes e lhes conferir o poder. (FERNEUIL apud BUZAID, 1968, p. 105)

"Se o povo não se expressa diretamente no governo, cabe ao estado convocar o governo dos melhores”. Assim Buzaid evoca Carl Schmitt, jurista do nazismo também crítico ao jusnaturalismo liberal, para fixar a "necessidade de dar à democracia um conceito específico e substancial de igualdade, haja vista que "a simples circunstância de ser figura humana não pode oferecer fundamento nem a um estado, nem a um regime político, nem a uma forma de governo", sendo que dessa simples circunstância - a vida - "não se podem obter distinções e delimitações" (BUZAID, 1968, p. 105). O conceito schmittiano de igualdade, assim, é incorporado por Buzaid: "toda igualdade recebe seu significado e sentido mediante a correlação com possível desigualdade”, motivo da democracia política não poder "basear-se na indistinção de todos os homens, senão só tendo em conta um povo determinado". Conclusão: “o conceito central de democracia é povo, não a humanidade. Se a democracia há de ser uma forma política, só pode haver democracia do povo e não da humanidade" (SCHMITT apud BUZAID, 1968, p. 105).

$\mathrm{Na}$ conclusão de seu "estudo da essência da democracia", após analisadas as três "experiências universais" - a democracia política liberal perempta, a democracia popular marxista-leninista que, "supondo que a salvação do regime se encontra na igualdade aritmética”, tiranizou-se com a ditadura do partido único, e a democracia social -, Buzaid adverte as diferenças substanciais entre essa "terceira via" proposta e o democraticismo, desaconselhável aos olhos do jurista. Citando Gustav Radbruch, Buzaid alerta para não se concluir que “"o ponto de partida da ideia democrática seja o relativismo, nem que o democraticismo seja a vontade de confiar o poder do estado à maioria do momento, sem considerações sobre o conteúdo de sua concepção política" (RADBRUCH apud BUZAID, 1968, p. 107). Interditando o sufrágio universal como o apanágio democrático, Buzaid expõe - no contexto de um Brasil ditatorial - seu autocratismo antipopoular:

Reduzir a democracia a um simples jogo da vontade flutuante da maioria ocasional, que através do sufrágio pode alterar a estrutura do estado, será negar-lhe a existência de conteúdo determinado, permitindo a destruição dos postulados que lhe caracterizam a base fundamental. Será destruir a liberdade de 
todos em benefício da opressão de alguns, que detêm o poder. (BUZAID, 1968, p. 107)

Ou seja, o sufrágio universal, entrelido como ameaça ao conteúdo determinado da democracia social buzaidiana que convocaria o governo dos melhores, deveria ser interditado para salvar a democracia do "suicídio". Democracia, aí, é lida como uma "conquista do progresso sem violência, sem intolerância, sem cumplicidade criminosa", reconhecendo não se tratar de "um regime paradisíaco" (BUZAID, 1968, p. 108). Assim, explicita-se o vinco cristão do autocratismo inscrito na proposta de democracia social buzaidiana:

A salvação da democracia está substancialmente numa rigorosa consciência das ideias de liberdade, de igualdade e de fraternidade; numa sincera adesão a uma concepção cristã de vida, mediante renúncia do supérfluo, do luxuário e do ostensivo, transmitindo ao próximo uma filosofia de amor, capaz de elevar os pobres e redimi-los da miséria; num acendrado espírito de justiça social, que substitua a ação de piedade em favor dos humildes por uma política de reabilitação; na dignificação do trabalho, imposto como um dever de todos; na espiritualização da vida, libertando-a das preocupações de gozo dos bens materiais; enfim, na recristianização da pessoa, dando-lhe o significado de seu destino transcendental (...). Democracia é espírito, é mística, é consciência pública; é integração do povo na vida do estado, indiretamente por seus mandatários e diretamente por sua diuturna vigilância, aplaudindo ou reprovando o governo, repudiando os que a traem e reconduzindo os que a servem, lançando no olvido os indignos e celebrando com alvissaras os bons, os justos e os virtuosos. (BUZAID, 1968, p. 108)

Nesse esforço de "salvar” a democracia, expondo uma concepção cristã de vida calcada na espiritualização do mundo e na recristianização da pessoa humana, contrário aos materialismos burguês e marxista, Buzaid formula proposição ideológica que lhe acompanharia, pouco depois, à testa do Ministério da Justiça da ditadura Médici. Esse processo de "salvamento" se confundiria com a "racionalização" da democracia (e mais adiante se apontará que ratio não-racionalista é esta). Assim, o diretor da FDUSP empossado em 1966 sugeriu a criação de um Instituto de Ciências Políticas junto às Arcadas para o estudo do fato político e para a formação de novos estadistas. Seria indispensável "criar, junto às Faculdades de Direito, o Instituto de Ciências Políticas para a formação dos homens públicos no Brasil” (BUZAID, 1968, p. 109). Nisso consistiria, precisamente, o "processo de racionalização da democracia", evidenciando-se, aqui, o vinco tecnocrático e antipopular do ideário buzaidiano. Neste, "quanto mais se aperfeiçoam os conhecimentos humanos, tanto mais se tecnicizam os especialistas. A civilização moderna 
não tolera que o curandeiro clinique, que o leigo advogue, que o mestre de obras levante arranha-céu” (BUZAID, 1968, p. 109). Na alegada tecnicização do Poder Judiciário, representação indireta da soberania popular, Buzaid buscou o Norte "racionalizador" dos demais poderes da República, "salvando a democracia" do sufrágio universal liberal e/ou da subversão comunista. Com o espírito juscorporativo, afirmando que "dentro da democracia, qualquer que seja, há sempre um corpo de juízes", conclui:

Ora, a civilização moderna dignificou a magistratura, criando a carreira e cercando os juízes de garantias para subtraí-los às influências da corrupção e dos grupos de pressão econômica. Se a magistratura togada constitui um dos poderes do estado, porque não cuidar dos demais com o mesmo zelo, revalorizando-os pela inteligência, pelo saber e pela honradez? (BUZAID, 1968, p. 109)

Ao exercitar seu politicitismo/juridicismo, Buzaid estabelece que "a elaboração das leis é uma das atividades fundamentais na política de um povo", "não se pode conceber um legislador que ignore a ciência da legislação" e defende que, se a administração é "a chave da política do estado" que exige "planejar, vincular os dirigentes a um ideal e aperfeiçoar as instituições realizando o bem público", não se poderia igualmente admitir que "um administrador desconheça a coisa pública" (BUZAID, 1968, p. 109). Assim, o teor aristocrático da democracia social defendida por Buzaid interditaria sindicatos e eleições, propondo-se a tecnicização/racionalização da representação popular indireta pela formação de homens públicos.

Um dos pontos mais altos no esforço de salvar a democracia é a revalorização dos homens públicos, cuja escolha não pode ficar à mercê das massas através de hábeis controles sindicais. Não pode ser homem público qualquer ignorante bafejado por poderosas influências eleitorais, mas quem possui aptidão no saber e vocação para o bem comum. (BUZAID, 1968, p. 110)

Como se observará, alguns anos após deixar a diretoria da FDUSP, Buzaid utilizaria exatamente esse argumento de tecnicização/racionalização dos poderes da República para conferir legitimidade/legalidade "democráticas" ao terrorismo do estado brasileiro, enquanto ministro da Justiça da ditadura medicista. Um pouco antes, porém, na antessala da Pasta da Justiça Médici, já então como magnífico Reitor da USP, em outubro de 1969 Buzaid defende - em apoio ao recrudescimento ditatorial pós-AI-5 - que no momento "em que um vendaval demolidor procura abater os valores da tradição, a Faculdade de Direito os cultua sem reserva, certa de que a sua defesa representa ao que há de grande na história do Brasil" (BUZAID, 1969, p. 386). É importante notar que a FDUSP consistiu no lócus de incubação ideológica perfeita 
para a ditadura militar recrudescida, que levara ao Ministério da Justiça do ditador Costa e Silva o professor uspiano Gama e Silva e, depois da indicação pela Junta Militar do general Médici para a presidência da República, também alçaria o professor Buzaid para a tarefa de "pentear" as leis ditatoriais com verniz técnico-jurídico adequado.

\section{O jurista oficial do bonapartismo medicista: o estado "revolucionário" de justiça}

Assim que galgou a chefia da Pasta da Justiça de Médici em 1969, Buzaid proferiu seu primeiro discurso enquanto ideólogo oficial ditadura recrudescida em $1^{\circ}$ de abril de 1970. Intitulado Rumos políticos $d a$ revolução brasileira, o discurso foi epigrafado com a frase atribuída a Péricles por Tucídides: "temos uma Constituição que não se modelou em nenhuma outra, mas que, antes, é um modelo para as outras”. Quem conseguiria cobrir a ditadura militar brasileira de originalidade constitucional à la Atenas, exaltar o heroísmo dos guerreiros e defender, até as últimas consequências, o mando militar ad aeternum, senão um jurista de passado integralista? Trata-se de fato histórico que merece ser reconhecido e refletido, sobretudo em seu lócus de origem, a FDUSP, a fim de se compreender a responsabilidade desta Faculdade ao traçar "os destinos da Pátria na obra de seus filhos" nos anos de chumbo.

As teses centrais do diretor designado em 1966 nuclearam e estruturaram o ideário oficial do ministro da Justiça Buzaid. No seu primeiro discurso ditatorial, citando referida passagem de Péricles, o ministro pontua que ela teria o "mérito de definir, em uma síntese, a consciência de um povo, que procura reencontrar-se consigo ao compor o seu Código Político, determinar a estrutura orgânica dos poderes e legislar sobre o complexo dos direitos e deveres sociais" (BUZAID, 1970, p. 7). Para ele, a melhor Constituição não seria o "documento ideal elaborado para reger seres imaginários, mas a lei fundamental de um povo adequada à sua formação política e capaz de traduzir os seus anseios" (BUZAID, 1970, p. 8).

Ao conceituar a contrarrevolução de 1964 como uma autêntica revolução brasileira, Buzaid salienta que ela se distinguiu "de outros movimentos armados" por visar "o interesse e a vontade da nação", alegando que "a Revolução não nasceu de uma quartelada", mas antes teria configurado um "brado de independência e das Forças Armadas, que se identificaram num ideal comum” (BUZAID, 1970, p. 8). Em suma, teria o povo, em geral, saído às ruas "em marchas eloquentes por Deus, pela pátria, pela família”, junto às "forças rmadas, cuja política de segurança fora preparada pela Escola Superior de Guerra”, pondo "abaixo um governo sem moral, sem dignidade e sem decoro” (BUZAID, 1970, p. 8) 
Buzaid advertia, após a "vitória da Revolução", que os "revolucionários" não seriam capazes de definir seus ideais ou de saber o que queriam: "não se apresentam com uma doutrina clara, ordenada e metódica" (BUZAID, 1970, p. 8). Os arrogados "revolucionários", na dicção buzaidiana, limitavam-se “a dizer o que não querem”, o que lhes repugnava na ordem política e social de então: "não querem a corrupção, que avilta administradores, juízes e legisladores; não querem a subversão, porque ela é uma forma de violência que degrada a criatura humana" (BUZAID, 1970, p. 8). Os nódulos ideológicos de combate à corrupção e à subversão, porém, configurariam apenas o polo negativo do ideário 1964. Se pelo aspecto subjetivo a (contra) "revolução" de 1964 fora realizada por "uma plêiade de idealistas", uma vez vitoriosa ela deve formar seus quadros. "Os revolucionários têm o poder de destruir a ordem instituída, mas não raro carecem da vontade de construir a ordem nova": precisariam se apartar da "ideia de revolver" (BUZAID, 1970, p. 9).

De acordo com o ideólogo bonapartista, "uma revolução no sentido verdadeiro da palavra traz uma mensagem de renovação", elabora a sua filosofia política e preocupa-se em assumir "um compromisso ideológico com o futuro" (BUZAID, 1970, p. 9). Por isso, Buzaid arrola as "conquistas" alcançadas no pós-1964: a fundação de novas bases de "uma política de desenvolvimento racional”, a outorga do Estatuto da Terra no domínio agrário, um conjunto de reformas econômicas que "no domínio das relações entre patrões e trabalhadores assegurou um clima de compreensão e coexistência pacífica", as reformas legais e codificações "no domínio da justiça”, inovações "no domínio dos transportes" e "das comunicações", bem como o papel de alto nível reservado às Forças Armadas que, "como instituições nacionais, executam a política de segurança nacional, defendendo a Pátria” (BUZAID, 1970, pp. 10-1).

Na medida em que retoma a mesmíssima tese da "racionalização" da democracia já exposta em seu discurso de posse de diretor da FDUSP de 1966, Buzaid aduz que a "Revolução Política" de 1964 "enceta, em seu terceiro governo, no plano das instituições políticas, a racionalização dos Poderes, em que se exprime a soberania nacional” (BUZAID, 1970, p. 11). Amparado na Constituição de 1967 emendada em 1969, Buzaid defende que no Brasil "todo o poder emana do povo e em seu nome é exercido" e, logo em seguida, retoma a argumentação de seu discurso de posse de 1966: se as concepções dos séculos XVIII e XIX identificavam democracia com a soberania do povo, deveria ser descartado "este dogma do liberalismo político", de "valor genérico, porque enuncia a fonte do poder, mas não a maneira de exercê-lo" (BUZAID, 1970, p. 13). Ao retomar Burdeau, para quem "se é sempre o povo que governa, não é sempre o mesmo povo", Buzaid copia, como ministro da Justiça medicista, as mesmas lições de 
Tocqueville e Ferneuil utilizadas em seu discurso de 1966. Com Tocqueville, sugere pela segunda vez que "para os partidários da democracia importa menos encontrar o meio de fazer o povo governar que de fazer com que o povo escolha os mais capazes"; com Ferneuil, assinala novamente que "o estado democrático convoca o governo dos melhores" (BUZAID, 1970, p. 13).

Ao versar o tecnocrata sobre os mecanismos "Do Funcionamento dos Poderes" e para ilustrar "os defeitos da representação" no Legislativo e Executivo, Buzaid defende ser preciso "conhecer a história dos partidos políticos no Brasil”, resgatando as querelas do Império entre os partidos Liberal e Conservador, o localismo oligárquico da Política dos Governadores na República de 1889 e a mudança do eixo político da República Velha pela "Revolução de 1930", quando "entra em declínio a Política dos Governadores, recebendo seu golpe mortal com a outorga da Constituição de 1937" (BUZAID, 1970, pp. 16-7). Na leitura buzaidiana, “a primeira tentativa de implantação de partidos nacionais surge com a Constituição de 1946”, indicando a história da UDN, do PSD e do PTB. Os dois primeiros não se distinguiram "substancialmente por programas ou doutrinas"; o PTB atuaria "nos sindicatos diretamente sobre os operários". Com a proibição do Partido Comunista depois da II Guerra Mundial, conforme Buzaid, "os comunistas procuravam dominar o PTB na esperança de levantar as massas trabalhadoras para a revolução social” (BUZAID, 1970, p. 18). Ainda que o trabalhismo petebista, objetivamente, em nada se assemelhasse à proposta de revolução social, Buzaid o pintava de vermelho comunista.

Nesse passo, o ministro Buzaid construiu a seguinte leitura do pré1964: dominavam ali "duas categorias de políticos", os empreguistas, "que velavam por seu reduto eleitoral, mantendo-o à força de distribuição de empregos", e os demagogos, "que se valiam de promessas de trabalhadores, embaindo-lhes a boa-fé" (BUZAID, 1970, p. 19). A ditadura, porém, haveria saneado o nefasto nó do status quo ante 1964, qual seja: “o grande drama dos partidos políticos brasileiros consistiu em desenvolver assim uma política de homens", isto é, "sem obediência a uma doutrina", resultando num "vertiginoso declínio" da "representação popular" (BUZAID, 1970, p. 19). Amparado na Constituição bonapartista de 1967, na qual "a representação não é uniforme nos três poderes" - "salvo a eleição do presidente da República, os mandatários do povo, no poder legislativo e no poder executivo, são escolhidos por sufrágio direto e universal dentre nomes indicados pelos partidos políticos" (BUZAID, 1970, p. 14) -, o ministro da Justiça Buzaid repõe idêntico argumento antes sustentado como diretor empossado da FDUSP em 1966: se nos poderes legislativo e executivo "a representação popular não alcançou o desejado 
progresso científico, já as coisas se passavam de modo diverso com o poder judiciário, que recebe cuidadoso tratamento dos últimos legisladores constituintes" (BUZAID, 1970, p. 20).

Novamente, o cariz antipopular do Judiciário como norte teria o mérito de dar lições aos demais poderes sufragados para que racionalizassem/tecnicizassem a representação popular (indireta). O judiciário, nessa visão buzaidiana, seria o "governo dos melhores" aludido pelo ideólogo, na medida em que "o ingresso na magistratura se realiza mediante concurso de provas e títulos", "não é constituído por magistrados eleitos pelo voto popular” (BUZAID, 1970, p. 20). Eis aí, saúda Buzaid, “o cuidado de selecionar tais representantes do povo", com "promoção por merecimento e antiguidade", "podendo o estado afastar aqueles que se tornaram indignos da representação". Em uma palavra, eis aí a louvada "racionalização do poder judiciário", que "não nasceu por acaso nem por engano" (BUZAID, 1970, p. 21). "O concurso de provas e títulos" configuraria, pois, "um dos meios de selecionar os melhores para o exercício da função" no judiciário, que deveria servir de exemplo "racionalizador" dos poderes legislativo e executivo. Para o ministro, "a lição que se tira dessa conquista brasileira não está, porém, apenas em exaltar os méritos do processo de seleção, mas especialmente em cotejar a conquista do Poder Judiciário, pondo-o em confronto com a escolha de representantes do povo nos dois outros poderes" (BUZAID, 1970, p. 21).

Mais claro, impossível. Abordando o "sistema constitucional vigente" em 1970, Buzaid destaca "que, dentre os poderes do estado em que se manifesta a soberania nacional, um deles procurou racionalizar-se, assegurando uma representação do povo qualitativamente excelente, porque escolhida mediante concurso de provas e títulos" (BUZAID, 1970, p. 22). Tomando o Judiciário como norte racionalizador da representação popular nos demais poderes de estado, Buzaid elogiava a "Lei complementar de Inelegibilidade" instituída pela Emenda Constitucional n. 1, de 1969, que buscaria "preservar a normalidade e a legitimidade das eleições", exigindo-se candidato moralmente digno e politicamente capaz. Exaltando também o "Código de Partidos" e rebatendo críticos, negava que fossem "tais exigências (...) um limite à liberdade de representação". " $O$ povo jamais quis escolher, como seus representantes, os maus elementos. Mas pode ser enganado por candidatos fecundos de promessas falaciosas" (BUZAID, 1970, p. 26). E foi justamente em defesa disso, no ideário bonapartista buzaidiano, que "veio a Revolução" Redentora, isto é, "para expurgar da política tais vícios, preconizando novo sistema de escolha de representantes do povo", buscando o Brasil pós-1964 "aplicar ao mundo política uma verdade elementar adotada sem discrepância pela nossa legislação" (BUZAID, 1970, p. 26). 
E qual seria esta verdade ressabida? Novamente, Buzaid opera uma reposição do discurso de posse da FDUSP de 1966: para medicar, exige-se diploma médico, para advogar, diploma de bacharel, para construir prédios, diploma de engenheiro. Isso tudo "para mostrar que, na sociedade moderna, quem não tem capacidade, reconhecida por lei, não pode exercer profissão" (BUZAID, 1970, p. 27). A conclusão buzaidiana, pois, veio em fórmula de pergunta retórica: "Se tantas exigências são feitas para $o$ exercício de profissões que interessam a toda a sociedade, como não se proceder à racionalização dos mandatos eletivos, impondo-se a escolha dos mais capazes e dignos da representação popular?" (BUZAID, 1970, p. 27). Analogicamente, conclui Buzaid, "na verdade, a partir da Constituição de 1967, o povo tem direito a uma legislação, que o oriente e o ampare na seleção dos seus mandatários", sendo que "um dos méritos da Revolução de 31 de Março foi o de considerar a política como uma ciência e institucionalizá-la como ética". Antes de 1964, situação saneada pela ditadura, Buzaid sustenta que a política teve "o fadário de se desenvolver como ação meramente empírica, variando segundo as vicissitudes ou contingências dos fatos" (BUZAID, 1970, p. 27).

Para o ideólogo bonapartista, passara a fase da política empírica dos homens; 1964 seria a nova política baseada em uma doutrina alinhavada, "científica" e ética. Vislumbrando a política "como doutrina e como corpo de princípios", assinala Buzaid que "a ação do governo traduz uma Filosofia do estado e uma concepção geral do homem", consistindo em mais "um dos méritos da Revolução de 31 de Março" o fato de estampá-las claramente (BUZAID, 1970, p. 26). É assim que o jurista de Médici divide a política, com Tomás de Aquino, em "ciência prática" e "disciplina moral". A "ciência política, considerando a boa ordenação dos homens, versa sobre a sua ação e assim se inclui entre as disciplinas morais" (BUZAID, 1970, p. 28). Também recorre Buzaid ao espanhol José Luis Aranguren - falangista que, em 1937, urgira para a necessidade de unificação doutrinária do nacionalismo do "nuestro caudillo y jefe nacional el general Franco". Citando Ética e política do falangista, Buzaid relembra que "o vocábulo 'estado' conduz ao estudo das categorias jurídicas, isto é, categorias puramente formais, quando justamente o que importa é separar bem, desde o início, a ciência política da teoria geral do estado. O que preocupa a ciência política é o que existe 'atrás' do estado, ou seja, as forças políticas reais" (ARANGUREN apud BUZAID, 1970, p. 28).

$\mathrm{Na}$ sequência, Buzaid conceitua "o verdadeiro fim do estado, segundo a concepção tomista": isto é, "a realização do bem comum", "tanto do povo quanto do indivíduo" (BUZAID, 1970, p. 28). Depois de citar Tomás de Aquino, Buzaid recorre à filosofia tomista do direito, na qual o bem comum como o telos do estado precisa de um meio de realização. 
"Para realizar o bem comum, a democracia precisa tecnicizar as funções do estado", "substituindo os políticos empíricos por políticos capazes, geralmente economistas e professores, que se preocupam em preparar o plano de desenvolvimento" (BUZAID, 1970, p. 30). Buscando "um conceito funcional de governo", o ministro da Justiça retoma que "a democracia ocidental, esclarece Aranguren, se acha em função do desenvolvimento econômico da nação” (BUZAID, 1970, p. 31). Em operação politicista, todavia, adverte que "a valorização do elemento econômico não significa uma diminuição do elemento político. Significa, ao contrário, uma ampliação do campo da política, que passa a abranger o plano do desenvolvimento e da expansão como uma das metas para atingir o bem comum" (BUZAID, 1970, p. 31). A política, assim concebida e ampliada ao papel de demiurgo e gestor da sociabilidade, incluiria "a renovação científica da administração pública" e a indicação por partidos políticos, não de "nomes de carreiristas, de demagogos ou de salvadores carismáticos, mas sim os programas de desenvolvimento capazes de sensibilizar o povo" (BUZAID, 1970, p. 31).

Eis que "a finalidade dos partidos políticos é chegar ao poder para pôr em execução uma doutrina ou um programa”, reafirmando Buzaid, com o jurista argentino Quintana Linares, "'a necessidade de promover uma política de ideias e não de homens" (LINARES apud BUZAID, 1970, p. 31). Destacando a natureza ética da política com o dominicano Louis Lachance, Buzaid assevera, no vinco cristão de seu ideário, que "S. Tomás sustenta que a ética é o gênero, do qual a política é a espécie”, concluindo que "a política se contém na ciência que trata dos entes morais", "é uma ética especial, uma forma de saber moral" (LACHANCE apud BUZAID, 1970, p. 33). Retomando L'humanisme politique de Saint Thomas d'Aquin, de Lachance, Buzaid conclui que "a ética ministra, portanto, à política seus princípios”, tendo a ética e a política, pois, "o caráter de ciências práticas" (BUZAID, 1970, p. 33). O clamor por ética na política, como se nota, não é de hoje. Recordando "um mandamento transcrito por Max Weber" - "tu deves opor-te ao mal pela força, senão serás responsável por seu triunfo" , Buzaid evidencia o teor cruzadístico de sua ideologia: "Ainda que se considere que a política não seja natural e necessariamente ética, a verdade é que deve sê-lo, porque, dada a versatilidade dos atos humanos, há uma luta inegável entre a prática do bem e do mal” (BUZAID, 1970, p. 34).

Guerra santa do bem contra o mal, vale-se Buzaid de Charles Journet, teólogo suíço e autor de Vues chrétiennes sur la politique, para enunciar que "para o cristão não se pode separar a moral da política" e que, se é verdade "que não [se] encontrará em S. Tomás de Aquino a expressão política cristã", ele "deu todos os meios de uma política fundada 
na ética” (BUZAID, 1970, p. 34). Buzaid destaca, assim, "a posição do cristão em face do problema das relações entre a moral e a política", afirmando que "uma criatura sujeita à Lei de Deus enunciada nas Escrituras Sagradas", diferentemente do ateu, está aderida a "fazer como pessoa" o mesmo que deve "fazer como cidadão e como homem público" (BUZAID, 1970, p. 35).

A política é eminentemente dialética, mas não exonera a pessoa do dever de cumprir as leis éticas. A posição do cristão, posto em confronto com a do ateu, é verdadeiramente dramática. $\mathrm{O}$ ateu pode ter altas virtudes, ser homem honrado, praticar conduta exemplar. Mas, sujeito apenas aos frouxos laços impostos pela convenção social, está sempre livre de agir de modo diferente, rompendo com os compromissos que espontaneamente aceitou, porque a sua obrigação moral não funde numa ordem sobrenatural. O cristão, ao contrário, é obrigado a cumprir as normas de uma moral, cujos princípios lhe foram transmitidos pela mensagem divina da fé revelada. (BUZAID, 1970, pp. 35-6)

A guerra santa ou cruzada do cristianismo contra o ateísmo, pelas mãos de Buzaid, deveria acrescer "uma lição do Cardeal Mercier, Pages choisies”: “o ateu consciente de seu ateísmo não tem obrigação de ser honesto", "as pessoas honestas sem religião não têm qualidade para opor obrigatoriamente a ordem à anarquia” (MERCIER apud BUZAID, 1970, p. 37). Foi por isso, segundo Buzaid, que "nas relações entre a moral e a política, deu o direito constitucional brasileiro, sob a inspiração revolucionária, um passo decisivo"; ele "não cuidou apenas da moral individual do político antes de assumir as suas funções no estado, quando escolhido pela vontade popular" (BUZAID, 1970, p. 37). "Se considerasse o político apenas sob este aspecto, a moral estaria fora do estado" (BUZAID, 1970, p. 37), mas, pelo contrário:

\begin{abstract}
A Revolução de 31 de Março objetivou institucionalizar a moral dentro do estado, sustentando que a política sem ética se torna vazia de valores, passa a ser antes uma ciência de dados da experiência que ciência do comportamento social. (BUZAID, 1970, p. 38)
\end{abstract}

Ao demarcar o vinco católico de seu bonapartismo, Buzaid amparase em L'enseignement 'politique' de l'Église, de R. P. A. Desqueyrat, sustentando ser impossível a neutralidade moral: "um estado sem moral passa a ser um estado sem moralidade", concluindo que "toda constituição supõe uma filosofia do homem e do cidadão" (BUZAID, 1970, p. 38). E a sua, prossegue, amparara-se em lições da Doctrina politica de los papas, do basco Alberto Martin Artajom - contendo o cristianismo "uma norma universal de retidão moral que se aplica à vida política” -, bem como no monsenhor Olgiati (Il conceto di giuricita in San Tomaso d'Aquino). Assim, "da afirmação contida no texto se pode facilmente inferir a doutrina 
da eticidade do estado" (BUZAID, 1970, p. 38), enaltecendo a esfera da politicidade e do estado como a dimensão por excelência da racionalidade, da ética e da moralidade humanas.

No encerramento de seu discurso, Buzaid retoma o argumento sobre ser "incontestável que o Brasil adota um regime democrático, ao afirmar que os poderes do estado emanam do povo", repisando "que o grande problema não está em dizer o que o político é, mas como o político deve ser; que a solução da crise da representação política não consiste em proclamar o que o povo pode fazer, mas como deve fazer" (BUZAID, 1970, p. 39). Segundo o bonapartismo buzaidiano, já "ninguém duvida que é preciso alterar a forma de representação, de modo que permita selecionar os mais capazes para exercerem o poder em nome do povo" (BUZAID, 1970, p. 39). Mas como e, mais importante, quem deveria reformar a representação política perempta? Para tanto, o ideólogo perspectiva como tarefa a mesma proposta de criação de um Instituto Político já exposta à FDUSP em 1966: "primeiro que tudo, formar o homem público em todas as áreas do saber e confiar o poder aos que têm aptidão para exercê-lo em nome do povo"; eis "a racionalização da representação do povo no poder legislativo e no poder executivo", que "deve ser a grande lição do terceiro governo da Revolução” (BUZAID, 1970, p. 39). Em resumo, “o povo não quer escolher quaisquer mandatários, mas aqueles que intelectual e moralmente sejam dignos de representá-lo" (BUZAID, 1970, p. 40), e "a Revolução, que age com esse intento, é verdadeiramente democrática”, "surpreende a vontade do povo nas suas fontes verdadeiras, desperta a sua vocação para participar nos destinos da história e o identifica com os governantes na mais pura das representações" (BUZAID, 1970, p. 40).

$\mathrm{Na}$ medida em que demarca sua particularidade continuísta dentro da Ideologia 1964, o ministro da Justiça Buzaid sustenta que a "Revolução constitui uma nova atitude do homem em face dos problemas fundamentais da Pátria. Para realizá-la, há necessidade de tempo, trabalho e perseverança no ideal” (BUZAID, 1970, p. 40). “A Revolução está em marcha. Uma Revolução que surgiu para valer por decênios não pode exaurir-se num único lustro. A ideia de revolver é substituída pela ideia de evolver” (BUZAID, 1970, p. 40). Na dicção do bonapartismo buzaidiano, “o que se infere de todo o exposto é que a Revolução de 31 de Março, entre vários caminhos, escolheu o da democracia” (BUZAID, 1970, p. 41). Mas que tipo de democracia? Essa seria mesmo a questão fulcral do ideário buzaidiano.

"Será democracia real o tipo que preconiza? Diz-se democracia real aquela em que o povo tem participação ativa no governo", um quadro "em que as eleições traduzem a vontade da nação, em que os mandatários honram as funções que lhes foram cometidas e em que a probidade 
administrativa e a moralidade dos candidatos sejam um penhor de confiança no cumprimento dos deveres" (BUZAID, 1970, p. 41). Apontando para a perfectibilização do mando autocrático burguês bonapartista, Buzaid afirma que a democracia real "está permanentemente in fieri, na ânsia de aperfeiçoar-se, banhando os seus fundamentos com valores éticos de validade universal" (BUZAID, 1970, p. 42). "Não é um fenômeno estático, não é uma expressão única, invariável e definitiva de instituição política” (BUZAID, 1970, p. 42). Revisitando Aranguren, o ministro Buzaid conceitua a democracia real da seguinte maneira: "esta concepção de democracia contém o chamado estado de direito, mas o supera porque tende a constituir-se em estado de justiça, que organizará a produção, manterá a ordem, realizará o equilíbrio dos interesses e assegurará a liberdade" (BUZAID, 1970, p. 41).

Aqui, foram retomadas e desenvolvidas as raízes ideológicas contidas no discurso de posse de Buzaid à Diretoria da FDUSP em 1966. Ali reside o emaranhado teórico mobilizado para posteriormente poder sustentar, enquanto ministro da Justiça, a ideia pela qual a ditadura militar seria um novíssimo (e autenticamente brasileiro) estado de justiça. Ressoando a "terceira" via do discurso de 1966, o estado "revolucionário" de justiça do ideólogo bonapartista retoma e aprofunda o caminho da democracia social cristã. Se o estado de justiça proposto pelo ministro Buzaid conteria e superaria o estado de direito liberal, o anticomunismo configuraria outro nódulo constitutivo básico de seu ideário bonapartista:

Porém, num estado de justiça ninguém pode admitir uma liberdade individual que gere desassossego coletivo, uma liberdade de terroristas que infunda o pânico na sociedade, uma liberdade de facínoras que assaltam a economia alheia, matam guardas, roubam metralhadoras e desafiam a autoridade constituída. (BUZAID, 1970, p. 41)

Ao retomar mandamento transcrito por Max Weber (BUZAID, 1970, p. 41) -, conclui Buzaid que "contra a ideia de liberdade para a prática do mal opõe a Revolução a ideia de liberdade para manter a ordem e promover o bem comum" (BUZAID, 1970, p. 41). O arguto jornalista Carlos Castello Branco (Castellinho), diante desse discurso de Buzaid, indignara-se com o ministro:

Difícil saber a quem se dirigiu o ministro da Justiça quando aludiu à ideia da "liberdade para a prática do mal". "Sabe o Prof. Buzaid nas suas horas de sereno recolhimento, que o estado de direito contém em si o estado de justiça, que não o supera por ser dele a simples decorrência. O estado de direito reduz a área de arbítrio. A ninguém, cujos objetivos sejam democráticos, ocorrerá reivindicar a liberdade para a prática do mal ou admitir uma liberdade individual que gere o desassossego público. Estranha a inspiração do ministro, ao criar a imagem que iria lhe servir, mais adiante para uma outra afirmação 
totalmente destituída de sentido, qual seja a da "ideia da liberdade para manter a ordem e promover o bem comum". (...) A repressão, nos limites da lei é instrumento normal para regular o exercício da liberdade. Jamais pode ser confundida com a própria liberdade, fator de afirmação da pessoa humana em que se compõe socialmente em termos de lei e ordem. A retórica ministerial leva-nos a supor que o Prof. Buzaid continua a vencer dificuldades tanto interiores quanto exteriores para ajustar-se a um papel em que deve reprimir dogmas da sua formação jurídica para servir a realidades que nem sempre previu ao assumir o Ministério da Justiça de um governo discricionário. Chamado a falar sobre ideias e generalidades, o ministro confunde-se e procura confundir-nos com teorizações abusivas, que de resto vão-se tornando rotineiras nas altas esferas oficiais. (CASTELLO BRANCO, 1979, p. 515)

Castellinho, depois de identificar a inversão de valores na alocução ministerial (na qual liberdade seria a libertação de amarras para o estado reprimir), clama pela restauração do estado de direito, combatendo a postura de Buzaid, o jurista da contrarrevolução permanente e da perenização do bonapartismo. Glosando a assertiva buzaidiana já vista, pela qual "uma Revolução que surgiu para valer por decênios não pode exaurir-se num único lustro" e na qual "a ideia de revolver é substituída pela ideia de evolver", Castellinho alfineta Buzaid, que "entendeu do seu dever tornar explícita a doutrina governamental". Discursou aos militares da ESG para "que não se preocupem com o processo político, pois a Revolução precisa de tempo, e sobretudo de ausência de tempo definido, para operar e realizar seus objetivos de promoção do progresso nacional. O ministro da Justiça não considera relevante a normalização institucional nem acha que o país se deva a esta altura preocupar com a organização de um estado de direito" (CASTELLO BRANCO, 1979, p. 599). Demarcando o teor de extrema-direita do bonapartismo buzaidiano, Castellinho afiança, acertando em cheio na conceituação do jurista ultraconservador, que: "Ele [Buzaid] prega a continuidade, senão a eternização do estado revolucionário. É a revolução permanente de um trotskismo às avessas.” (CASTELLO BRANCO, 1979, p. 599)

Sendo um agente da contrarrevolução permanente, Buzaid completou esta missão no núcleo de seu ideário bonapartista. "Eis que o ministro Alfredo Buzaid vai a eles [os estagiários da ESG]", prosseguia Castellinho, "para realizar junto deles o esforço contrário" à normalização institucional. "Ele foi convencê-los a não parar o processo revolucionário":

O ministro da Justiça não tem pressa de restaurar o regime e aconselha a todos que também não se apressem. São conhecidos e notórios os pressupostos doutrinários de tal atitude. Isso, porém, não importa. No caso do ministro, o que se passa é uma adesão à visão pragmática do governo que une todos os 
problemas num só, o do desenvolvimento. Isso dispensa de pensar em outros problemas, isso dá tempo ao Prof. Buzaid para fazer seus códigos. (CASTELLO BRANCO, 1979, p. 599)

Castellinho indigna-se também com discursos de Médici pelos quais seu governo perfilharia um tipo de democracia social. Critica, assim, o discurso medicista, que em tudo repisa as trilhas do ideário bonapartista de seu Ministro da Justiça, no qual "há a condenação formal ao que se chama de democracia 'ortodoxa e saudosista'. Nele fala-se no 'generalizado desencanto pelos caminhos do liberalismo político' e na 'incompatibilidade do liberalismo político com as violentas mudanças das estruturas socioeconômicas'. A Revolução, na sua forma atual, pretende acabar com as 'filigranas do velho jogo político' e, adepta do planejamento, pretende marchar coerentemente para a democracia social, só ela compatível com as tensões sociais geradas pelas mudanças econômicas" (CASTELLO BRANCO, 1979, p. 494). Equivoca-se Castellinho, porém, ao dizer que se estaria, no ideário medicista, "pelo menos em matéria de doutrina, em plena seara socialista" (CASTELLO BRANCO, 1979, p. 494). "Não é de presumir que os assessores incumbidos de redigir os documentos pessoais do presidente da República ignorem o significado das expressões que usam e das análises que registram", parecendo-lhe "um erro conduzir o presidente pelo caminho do debate doutrinário" (CASTELLO BRANCO, 1979, p. 514). Mesmo incorrendo em equívoco ao acreditar que "Democracia social, por exemplo, é expressão usada como sinônimo de forma socialista de governo", critica o jornalista:

Os assessores presidenciais evidentemente não pretendem transformar o General Médici num chefe de república popular ou socialista. A linguagem é aí usada torcidamente, com vistas a justificar uma situação que se coloca no polo oposto ao esquerdista e com intenção de motivar métodos emergenciais para torná-los, se possível, permanentes. A expressão empregada pelo Presidente da República adquire, sem que o perceba o General Médici, uma conotação demagógica, pois visa a acobertar uma supressão de liberdades com a promessa de liberdades mais eficazes. (CASTELLO BRANCO, 1979, p. 514)

Não obstante o engano quanto à matriz reacionária da democracia social buzaidiana, Castellinho acerta ao denunciar o afã de perenizar os métodos emergenciais por parte dos setores ultraconservadores da ditadura Médici integrada por Buzaid. Isso, talvez, por Castellinho não ter sido convidado para assistir a uma palestra na ESG, em 1972, do jusfilósofo Miguel Reale (ícone da elaboração política integralista na juventude, longevo parceiro de Buzaid desde o movimento do Sigma chefiados por Plínio Salgado, até a conspiração da FDUSP no Ipês paulista). Intitulada "Problemas institucionais do estado contemporâneo", Reale defende o ditador Médici, pontuando que "a crise do estado começa, 
na época hodierna, com a crise e o superamento do estado liberal" (REALE, 1972, p. 2), e mais: "o modelo experiencial da democracia social" estaria, no Brasil, "gerando formas de participação que não se reduzem ao mero exercício do voto" (REALE, 1972, pp. 10-1). Democracia social como um constructo subjetivo, "um termo calculadamente genérico e que não deve ser confundido com a 'social-democracia' pregada pelos marxistas revisionistas alemães” (REALE, 1972, p. 2). Defendendo Médici, o bonapartista Reale afiança que:

Quando o presidente Emílio Garrastazu Médici situa o problema político brasileiro em termos de 'democracia social' está, evidentemente, se referindo ao tipo de democracia que os povos, não alinhados na área soviética ou chinesa, procuram atingir, conservando o legado histórico do liberalismo, mas completando tais conquistas com o reconhecimento da função positiva do estado como fonte de progresso e de cultura, de liberdade e igualdade concretas e efetivas, a tal ponto que o estado de Direito se apresente, substancialmente, como estado de justiça social e da cultura. (REALE, 1972, p. 12)

Tal qual Castellinho, outro arguto jornalista - o liberal conservador Fernando Pedreira - também critica, valendo-se da teoria do autoritarismo e da identificação inadequada do integralismo com o fascismo, "a tentação de institucionalizar o regime" do governo Médici, "isto é, de transformar a situação autoritária, tão bem definida no estudo de Juan Linz, num regime autoritário permanente” (PEDREIRA, 1975, p. 279). Pedreira, inclusive, dá nome aos bois:

Esses partidários do presidente, civis e militares, capitaneados pelo seu ministro da Justiça, Alfredo Buzaid, eram homens de formação direitista, oriundos do Integralismo, corrente que, no Brasil dos anos 30, refletiu as ideias do fascismo e dos salazarismo europeus, e que deixou remanescentes numerosos, embora isolados, em algumas áreas da vida nacional. (PEDREIRA, 1975, p. 280)

$\mathrm{O}$ arremate de Pedreira, enfim, confirma as teses expostas até aqui: em discursos e pronunciamentos feitos em 1971-72, esse grupo procurou impingir ao sistema dominante e ao país uma doutrina antiliberal e antidemocrática, capaz de servir de base à institucionalização que desejava (PEDREIRA, 1975, p. 280)7.

\footnotetext{
7 Pedreira critica o "desejo - aparentemente tão forte em certos círculos do governo [Médici] - de declarar a falência do liberalismo político para melhor justificar a permanência do atual estado de coisas. (...) Se os assessores do general Médici dissessem com clareza qual é, afinal, o estado revolucionário que pretendem estabelecer no país". "A insistência dos assessores do presidente em condenar o liberalismo só pode ser considerada como uma amarga ironia” (PEDREIRA, 1975, pp. 176-7). Mas não era. Apesar da argúcia dos dois jornalistas liberais democratas citados, não compreenderam precisamente os fundamentos do bonapartismo buzaidiano e medicista no tocante à nomenclatura estado de justiça, democracia social etc.
} 
$\mathrm{Na}$ defesa do evolver permanente da contrarrevolução de 1964, também ecoando a mobilização juvenil que inspirara o integralismo histórico, Buzaid arremata que "compete aos moços tomar agora a bandeira da renovação de costumes”, devendo "preparar-se para a vida pública, conhecendo os problemas políticos que interessam ao Brasil e ao mundo". "A história reserva-lhes uma tarefa decisiva nos destinos da Pátria, a partir do momento em que, preparados intelectual e moralmente para a vida pública, forem investidos nos altos cargos do estado" (BUZAID, 1970, p. 40). Aqui Buzaid repõe a mesma mensagem contida anos antes em seu discurso de posse na diretoria da FDUSP: "O que lhes cabe, agora, é estudar. Depois saberão agir sem agitar, resolver os problemas sem tergiversar, construir o futuro sem malograr", retomando que "uma geração de moços, que não participa da vida política, que se omite, que busca o luxuário, que se compraz no gozo dos bens materiais, carece de espiritualidade, de calor humano, de nobreza de ideias" (BUZAID, 1970, pp. 40-1).

Diante do exposto, vê-se que os maiores expoentes jurídicos paulistas, Miguel Reale e sobretudo Alfredo Buzaid, intentaram impingir, como verniz doutrinário da ditadura Médici, a alcunha do estado de justiça (ou da justiça social e da cultura), uma democracia real autenticamente brasileira, in fieri, em permanente aperfeiçoamento. $\mathrm{O}$ evolver no lugar do revolver. O ministro da Justiça Buzaid, de modo direto, já dissera à imprensa que "as eleições indiretas são tão democráticas quanto qualquer outra” (Veja, ed. 188, 12 abr. 1972, p. 20), mas também o fizera de modo mais complexo em longas exposições doutrinárias dobre o ideário da "revolução democrática brasileira" de 1964 .

Na medida em que se retoma o vinco reacionário cristão do ideário buzaidiano, que ecoou a mais profunda raiz ideológica (não impressa), explicita-se que sua visão de mundo foi construída sob o signo do integralismo de Plínio Salgado. Porém, com uma "pequena" diferença: Buzaid mobilizaria o ideário regressivo pliniano não mais nos anos 1930, mas décadas depois, como Ministro da Justiça da ditadura Médici (196974). Isto é, o vinco cristão-integralista do ideário buzaidiano haveria de se recompor e fundir, a seu modo, à ideologia de segurança nacional e desenvolvimento da ditadura militar brasileira.

Os "pressupostos doutrinários" da ação ministerial de Buzaid configuram os pressupostos ideológicos “ocultos" que religam o bonapartismo buzaidiano ao velho integralismo de Plínio Salgado. Antes disso, todavia, valeria adensar um pouco mais o bonapartismo buzaidiano, explicando que ratio autocrática propugna. Na alocução "Marxismo e Cristianismo (O problema do ateísmo)”, Buzaid demarca, em 1970, a 
influência cristã de seu ideário bonapartista, interditando o diálogo entre cristianismo e marxismo. "Os cristãos precisam" combater o marxismo, "anunciando que a solução dos problemas sociais não é privilégio dos comunistas. A Igreja tem uma mensagem, tendente a corrigir os males dos tempos atuais" (BUZAID, 1970, p. 51). No mesmo ano, na alocução "Em Defesa da Moral e dos Bons Costumes" Buzaid propaga o conteúdo cristão anticomunista de seu bonapartismo, alegando que o estado deve se defender "contra os agentes do comunismo internacional" e por isso a Constituição do Brasil "considera como inimigos da pátria os que promovem a propaganda de guerra, da subversão da ordem, do preconceito religioso, étnico ou de classe, bem como os que fazem publicações e exteriorizações contrárias à moral e aos bons costumes" (BUZAID, 1970, p. 15). Seu télos e fundamento: "preservar a integridade da família brasileira e a sua moralidade tradicional, combatendo destarte o comunismo internacional, que insinua o amor livre para dilacerar as resistências morais da nossa sociedade" (BUZAID, 1970, p. 41).

Em "O estado federal brasileiro" (1971), no entanto, o ministro Buzaid define o Direito Constitucional cingido à análise do "regime federativo sob dois prismas fundamentais; a) o do desenvolvimento econômico; b) e o da segurança nacional" (BUZAID, 1970, p. 16). Conceitua o federalismo de integração como um novo tipo de pacto federativo "que promove o desenvolvimento econômico com o máximo de segurança coletiva” (BUZAID, 1971, p. 41). Centralmente, é no discurso "A renovação da ordem jurídica positiva" que o ideólogo bonapartista define a "Revolução" de 1964 "como uma filosofia da vida, uma doutrina política, uma nova economia, uma concepção do direito. Por isso não pode excluir de sua missão reformadora nenhuma área do pensamento" (BUZAID, 1971, p. 9). Aqui, o bonapartismo buzaidiano acredita que "organizar um povo significa determinar-lhe a ordem jurídica. As relações sociais hão de ser disciplinadas por normas legais", arrematando que, "ao estabelecer o novo sistema jurídico, realiza a Revolução não só o progresso material, conforme a política do desenvolvimento, mas também o progresso moral, dignificando a pessoa humana" (BUZAID, 1970, p. 9). O que distinguiria, enfim, um processo revolucionário de um golpe de estado, para o então ministro Buzaid, seria a compreensão pelos vitoriosos de que a "Revolução" tem "a consciência de que, para alcançar os seus objetivos, há de rever a legislação", sendo a ordem jurídica positiva "a imagem de um povo" que "reflete-lhe os sentimentos, o gênio e a cultura". Eis que, na máxima buzaidiana, "a Revolução tem necessidade de legislar", sendo o direito não "apenas a voz que transmite seus anseios", mas "especialmente a consolidação dos seus ideais" (BUZAID, 1970, p. 13). O direito brasileiro, portanto, como a consolidação da ideologia contrarrevolucionária de 1964. 
É apenas em 1973, porém, na alocução "humanismo político", que se identificam elementos para responder, na imanência do texto buzaidiano, a uma pergunta deixada em aberto. De que ratio se trata quando Buzaid conceitualiza a "racionalização" da democracia? Trata-se da regressividade ideológica de uma ratio não racionalista, de matriz tomista. Romantizado o medievo, aponta que "a causa da crise oriunda do antropocentrismo do Renascimento, que desembocara "no desespero trágico do mundo moderno, foi a ruptura entre o temporal e o espiritual" (BUZAID, 1970, p. 35). A cisão temporal/espiritual, que iria do Renascimento ao marxismo-leninismo, exigiria a mão forte do estado de justiça: "quando a sociedade é sacudida por atentados, sequestros e piratarias, punem-se os delinquentes" e "o estado, procurando antes evitar tais atos do que reprimi-los, cria medidas de prevenção social, a fim de resguardar a maioria pacífica contra a minoria celerada", contra os “agentes da guerra fria, psicológica ou revolucionária, que torna indigna a pessoa humana e deteriora o bem comum” (BUZAID, 1970, p. 33). Contra o comunismo, no bonapartismo buzaidiano, "o humanismo engrandece a política", "considerada como ciência”, "concepção do estado”, "política científica [que] requer que os homens públicos se movam em torno de ideias" (BUZAID, 1970, p. 33). Se "cada povo tem uma alma”, "plasmá-la para realizar o bem comum quer dizer dignificar o homem”, "preparandoo no culto da moral e do civismo, da fé e da espiritualidade, do exemplo e do sacrifício, da honra e do dever" (BUZAID, 1970, p. 34).

$\mathrm{O}$ povo, que amadurece na experiência política, ama os estadistas austeros. Prefere que governantes equilibrados o conduzam segundo a lei orgânica do desenvolvimento natural (...). Um governo, quando tem ideais elevados e se empenha em realizações construtivas, pensa, antes de mais nada, no homem do seu povo que, embora distante, com ele está indissoluvelmente unido. E conquista a sua confiança, porque se identifica com o povo que representa. (BUZAID, 1973, pp. 345)

Ao retomar sua tese dantes exposta no discurso de posse como diretor da FDUSP, o ministro da Justiça Buzaid reelabora seu apostolado anticomunista e ultracatólico, crendo "que a missão mais importante dos crentes está em recristianizar o mundo através do apostolado em vez de se aproximarem dos que querem impor, como pensamento oficial, o banimento de Deus. Humanizar não significa fazer novo homem, mas recompô-lo em sua integridade" (BUZAID, 1970, p. 35). A ditadura Médici, assim, seria "um passo fundamental no sentido de restaurar a autenticidade brasileira e revelar o espírito criador dos seus juristas, militares e políticos, que compreenderam que cada povo deve encontrar, à sua maneira, a fórmula de sua salvação". Por isso "o espírito da Constituição deve traduzir uma concepção da vida e do mundo” (BUZAID, 
1972, p. 7), impingindo Buzaid ao medicismo toda regressividade ideológica que apenas um integralista, no Brasil, conseguiria fornecer.

De 1972, o discurso "Da conjuntura política nacional” é capaz de demonstrar a especificidade do teor regressivo do ideário bonapartista buzaidiano, basicamente ancorado no russo Nikolai Berdiaev: "a Renascença assinala o primeiro passo na ruptura entre o mundo natural e o mundo sobrenatural", enaltecendo "o homem, sua grandeza e seu poder criador, libertando-o do auxílio da Providência Divina”, "do século XVI em diante, quanto mais aumenta a exaltação da criatura, tanto mais diminui o seu vínculo ao Criador" (BUZAID, 1972, p. 14) ${ }^{8}$. Retomou, ainda, lição do padre Leonel Franca pela qual "o processo de dessacralização, que se inicia com o antropocentrismo da Renascença, finda com a antropolatria dos tempos modernos", faltando "apenas um passo para apregoar o banimento de Deus e a divinização do homem" (FRANCA apud BUZAID, 1972, p. 16). Revestido de verniz integralista, o bonapartismo medicista de Buzaid arremata: "em um mundo, que se divide entre os que creem em Deus e os que lhe negam a existência, a Revolução de 31 de Março partilha a doutrina espiritualista" (BUZAID, 1972, p. 17). Terrorismo planificado de estado, embora com fundamento doutrinário "espiritualista". A filosofia católica que Buzaid impingira à ditadura Médici, com eco integralista, teve de readequar-se, porém, à nova realidade da guerra fria e, mais especificamente, teve de se fundir à doutrina medicista de segurança nacional máxima com desenvolvimento acelerado.

Outro aspecto, o da luta antissubversiva da guerra fria, foi escancarado nos embates do ministro Buzaid, para quem "não há guerra mais cruel, mais odienta e mais traiçoeira do que a guerra subversiva" (BUZAID, 1972, p. 28). Se "os terroristas espalham a lei do ódio, da metralhadora e do sangue, destruindo vidas, provocando incêndios e semeando por toda a parte o pânico" (BUZAID, 1972, p. 29) é a forma como Buzaid conceitua a guerra revolucionária comunista com o general franquista Diaz de Villegas Bustamante, o vinco cristão anticomunista de seu bonapartismo é assim explicitado:

O povo brasileiro é o povo de Deus. Nasceu sob o signo da Cruz e em todos os momentos de sua história afirma a fé em Cristo. No preâmbulo de suas Constituições políticas proclama a confiança em Deus, Supremo Regedor do universo. Sob inspiração cristã está construindo o Brasil nova civilização, em que ao desenvolvimento material se superpõe a formação espiritual do homem (...). A missão dos crentes, num país em

\footnotetext{
8 O espírito de secularização ganha cada vez mais prestígio. Sob o aspecto filosófico, o individualismo, que recebe o mais alto bafejo da Renascença, evolui irresistivelmente e vai cavando a desagregação da cultura ocidental. A razão humana quer ser independente e soberana; sente-se capaz de julgar com seus próprios recursos, servindo-se dos atributos que lhe são imanentes (BERDIAEV apud BUZAID, 1972: 14).
} 
que o estado está separado da religião, consiste em preservar a fé, cultivar as lições do Livro Sagrado e defender o primado do espiritual contra o materialismo, qualquer que seja a forma com que se apresenta. (BUZAID, 1972, pp. 34-5)

No Brasil do estado "revolucionário" de justiça da ditadura Médici, na dicção de Buzaid, ao desenvolvimento material se superpõe a formação espiritual do homem. Importa notar que tal concepção espiritualista encontra suas raízes "ocultas" no integralismo de Plínio Salgado. Correlato ao caráter católico anticomunista, o antiliberalismo também se escancarou no ideário do bonapartismo buzaidiano. Criticando a ingenuidade da "atitude dos liberais" (BUZAID, 1972, p. 25) que, "em face dessa onda de violência, de crimes e de barbárie, que varre a face da terra", "acreditam na coexistência da democracia com o comunismo" (BUZAID, 1972, p. 29), Buzaid assegura a natureza democrática da ditadura militar brasileira recrudescida.

O Brasil realiza uma democracia de voto livre e de veto obrigatório. O voto é livre, porque se funda na legítima manifestação da vontade popular consultada através de eleições. O veto é obrigatório, porque obsta a que a democracia cometa suicídio. Este fenômeno se dá, quando ela se entrega docilmente aos que querem destruí-la. (BUZAID, 1972, p. 33)

\section{Raízes "ocultas" do ideário buzaidiano: o integralismo de Plínio Salgado}

As fontes ideológicas do bonapartismo de Buzaid enraizaram-se no integralismo de Plínio Salgado. Configuram-se como raízes "ocultas" na medida em que Buzaid, diferentemente do jovem Reale (com profícua publicação já na fase integralista), não produziu nenhum aporte integralista de relevo naquele período. Dessa forma, quem "lê" o bonapartismo buzaidiano sem levar em conta sua formação no seio do integralismo pliniano, necessariamente, deixa de apanhá-lo em seu significado histórico-ideológico concreto. Ao indicar as profundas marcas plinianas que "reapareceriam" no bonapartismo buzaidiano, aqui vale retomar a tese de J. Chasin, naquilo que ora interessa sobre a presença do ideário pliniano no pensamento tardio de Buzaid. Ali é possível identificar diversos núcleos integralistas plinianos que, décadas depois, reaparecem e fundam a particularidade do bonapartismo buzaidiano.

Centralmente, aquilo esboçado por Buzaid como a "revolução" de 1964, em muitos aspectos, identificou-se ou baseou-se na concepção espiritualista de "revolução" embandeirada por Salgado. O chefe do Sigma "defendeu uma revolução espiritual e de ideias, insistindo na tese da imprescindibilidade de teor doutrinário nos processos revolucionários. 'Não é possível conduzir uma revolução sem um pensamento central 
fixado com rigor"' (CHASIN, 1978, pp. 494-5). A mesma concepção, no segundo aniversário do golpe de 1964, "reapareceria" igualmente em Miguel Reale9. O teor espiritualista da "revolução" de 1964 inscrito, como se viu, no bonapartismo buzaidiano, fincou raízes neste legado pliniano. “Na perspectiva integralista, 'a 'revolução' deixa de ser a desordem individualista, classista ou partidária, para ser o direito do espírito de intervir no desenvolvimento das forças materiais da sociedade, recompondo equilíbrios segundo um pensamento de justiça'. Para o integralismo pliniano, pois, "a revolução é um ato de intervenção do espírito, na realidade, com o propósito de re-estabelecer, de re-por equilíbrios sociais" (CHASIN, 1978, p. 495).

Também o caráter da "revolução" permanente do bonapartismo buzaidiano inspirou-se no aceite pliniano do "princípio da permanência do fenômeno revolucionário (...) sob o critério espiritualista. O espírito é o permanente improvisador. Seu arbítrio soberano é que domina a marcha do mundo. É ele que escreve a história' (CHASIN, 1978, p. 497). No integralismo pliniano - naquilo que "reaparece" no discurso buzaidiano pós-1964 - sustenta-se que, “em face dos 'desequilíbrios sociais' que a expansão das forças econômicas provocam, impõe-se a intervenção revolucionária, que não é outra coisa do que a 'interferência de uma ideia no sentido de restabelecer um equilíbrio" (CHASIN, 1978, p. 504) 'A revolução integralista é permanente, porque será sempre a interferência do espírito humano recompondo equilíbrios sociais, de conformidade com os impositivos da moral e da finalidade superior do homem"' (CHASIN, 1978, p. 505).

Tal qual o Buzaid tardio, também Salgado reivindica "para a Revolução o seu caráter ético. A ideia revolucionária é sempre moral: compreende uma concepção de justiça e de equilíbrio que é presente em todos os movimentos da história" (CHASIN, 1978, p. 505). O ideário de Salgado, na dicção chasiniana, "não se trata de uma ideologia da ordem qualquer, mas de uma ideologia da ordem espiritualista, e ainda esta é particularizada, apesar de repelir dimensões confessionais, explicitando-se em geral como ideologia da ordem cristã, particularmente católica" (CHASIN, 1978, p. 508). A eticidade e moralidade do estado de justiça cristão, explicitadas no bonapartismo buzaidiano, também neste aspecto encontram sua filiação no integralismo pliniano, para o qual: “'O problema da transformação do estado subordina-se a uma concepção filosófica da qual decorrem as soluções dos problemas político e econômico. Partimos do princípio da autoridade moral do estado, do conceito ético do estado”

9 "Uma revolução pode, é certo, não derramar sangue, mas não pode deixar de derramar ideias" e "se foi bem inestimável termos tido uma 'revolução incruenta', ela nos dita o imperativo de revelar a posteriori as razões ideológicas subjacentes" (REALE, 1966, p. 283). 
(CHASIN, 1978, p. 508). O estado "revolucionário" ético e moral de 1964, como se nota, ecoaria tal matriz pliniana.

Especialmente a influência cristã no ideário bonapartista de Buzaid ressoaria na designada missão dos crentes na ditadura Médici. $O$ integralismo pliniano exibe também "uma visão ativista do cristianismo, onde Deus é o eterno revolucionário" (CHASIN, 1978, p. 512). "Os integralistas sustentam e proclamam o princípio de Deus, as tradições cristãs da nacionalidade, estão de pé na defesa dos templos" (CHASIN, 1978, p. 513). Centralmente, "Salgado edifica a revolução espiritualista na expulsão da revolução materialista”. Buzaid, no Ministério da Justiça de Médici, trava sua cruzada antimaterialista com as armas integralistas, combatendo o materialismo em qualquer que seja sua forma. Nesse vinco anticomunista de passado integralista, Buzaid perfilha a concepção pliniana segundo a qual "o comunismo é a última consequência de uma civilização materialista'. 'Capitalismo e o comunismo não passam de palavras diferentes para designar a mesma coisa: a brutalidade da violência, o materialismo grosseiro"' (CHASIN, 1978, p. 518).

$\mathrm{O}$ antimaterialismo, de fato antievolucionismo pliniano, "ecoa" no bonapartismo de Buzaid, retomando-se que "a recusa pliniana do evolucionismo marxista tem por raiz e é antecedida pela rejeição do evolucionismo capitalista. (..) Para o integralismo pliniano, 'o individualismo e o liberalismo, filhos do materialismo, lançaram as mais tremendas lutas sobre a terra'. E como suporte e continuador desta trágica herança, aparece o marxismo: 'A verdade é que o marxismo não passa de um capítulo acrescentado à economia burguesa. Ele é um continuador dos burgueses evolucionistas e materialistas" (CHASIN, 1978, p. 524; 525). "Em resumo, o pensamento marxista e capitalista estão atados pela raiz, expressando a concepção evolucionista de mundo, expressão esta que marca irrecorrivelmente o século XIX" (CHASIN, 1978, p. 525). Contra isso, tal qual Buzaid no Ministério da Justiça Médici, Salgado elogia o medievo contra o antropocentrismo. “A Idade Média é para Salgado o grande paradigma, a matriz da consciência moral de mundo: 'A Idade Média possuía a mais perfeita consciência do mundo moral, compreendendo o Homem e o Universo por uma forma total, isto é, sem exclusão dos valores espirituais. O centro de tudo era Deus, para o qual o homem se dirige", valor eterno, "a base única de toda a construção do estado e da sociedade” (CHASIN, 1978, p. 537).

A modernidade, pois, "significaria a "humanidade ateísta, cujas expressões mais definitivas começam no Renascimento, atingem elevada altitude no Enciclopedismo e na Revolução Francesa e prosseguem nos panoramas dos dias da Grande Guerra e do após guerra" (CHASIN, 1978, p. 537). A mesma linha pliniana que vai do Renascimento ao marxismo- 
leninismo seria mantida e reelaborada no ideário bonapartista buzaidiano. $\mathrm{O}$ anticomunismo pliniano, amplamente aprendido e compartilhado por Buzaid, centra fogo nos "“cavalos de Tróia de Moscou”, criticando o "veneno soviético" que "se insinuou, penetrou, corroendo estruturas [sociais]" (CHASIN, 1978, p. 555). "Em síntese, nada escapa à ação comunista De modo que, ou se vergam os liberais, ou sucumbe-se, um dia, ao comunismo. A supressão do liberalismo é, pois condição prévia da salvação nacional. Impõe-se, portanto, para a luta imediata o combate ao liberalismo, ao capitalismo, e para tanto a implantação do estado integral”, "instrumento da revolução espiritualista, dentro da concepção espiritualista da história" (CHASIN, 1978, p. 555). Impingindo eticidade ao estado, também o bonapartismo de Buzaid evoca a concepção de estado do integralismo pliniano. Neste, “'o conceito do estado, como o conceito da revolução, tem de ser forçosamente ético'. (...) O estado integral é um estado eticamente fundado (...). 'Hoje, nós pensamos em restaurar o equilíbrio social criando um estado ético. (...) Essa fonte de moralidade do estado é a família. Sem família não há estado ético" (CHASIN, 1978, pp. $557 ; 558)$.

O estado ético é o que se propõe manter o equilíbrio dos grupos, a fim de assegurar a intangibilidade do homem”. Lembre-se que, no ideário bonapartista buzaidiano, a defesa da família era o objetivo fundamental do estado "revolucionário". A concepção de estado integral pliniana, igualmente, fincou importante raiz ideológica "oculta" na ideologia oficial do bonapartismo buzaidiano. Para Salgado, com a "revolução" espiritualista fundar-se-ia um "estado integralista", para salvar o homem "da ditadura cruel do materialismo finalista (leia-se comunismo) e da ditadura sem finalidade da plutocracia democrática e das oligarquias políticas e financeiras. O estado, que defenda o Indivíduo contra a Sociedade e a Sociedade contra o Indivíduo", "que seja o impositor do equilíbrio, o mediador máximo, o juiz, o orientador, o propulsor”. Matriz ideológica também presente no bonapartismo de Buzaid, "do ponto de vista da concepção espiritualista da história, o evolver social é aferido pelas suas posições em face do divino, e a teoria da revolução espiritualista é a legitimação do ato humano que repõe a humanidade desviada no rumo certo de sua perene gravitação em torno do absoluto, compreende-se que o estado possa ser configurado, tal como fez Salgado, enquanto instrumento dessa operação" (CHASIN, 1978, pp. 542; 543). É assim que, para o integralismo de Plínio (com eco na visão buzaidiana da guerra fria), "ser 'revolucionário' é corrigir ou contrariar as determinações da matéria” (CHASIN, 1978, p. 543). "(...) O estado integral é designadamente, da ótica do ideólogo do sigma, o meio por excelência da efetuação dessa ‘insurreição contra a matéria”. "O estado forte de Salgado é por ele 
entendido como um 'estado revolucionário', “o pretendido executor de uma regressão histórica, que tem como pano de fundo uma crítica romântica ao capitalismo, de cujas formas mais efetivas o integralismo pliniano pretende se evadir" (CHASIN, 1978, p. 543).

Décadas depois dessas elaborações do integralismo de Salgado, Buzaid - apologeta oficial da perenização do "estado revolucionário" de 1964 - compõe a Ideologia 1964 num contexto em que a regressividade integralista, emprestada ao ideólogo do terrorismo de estado brasileiro, serviria propositivamente como agente econômico do capital atrófico e subsumido ao imperialismo. Longe de frear o desenvolvimento econômico, o terrorismo do estado ditatorial (que encontrou em Buzaid o seu jurista oficial) potencializou um novo padrão de acumulação capitalista. Buzaid serviu como cogestor à ditadura do grande capital e mesmo que imbuído da regressividade integralista, promoveu a ditadura militar recrudescida como agente propulsor do capitalismo brasileiro. Novamente, o $x$ da questão (apenas levantado) se coloca: se o integralismo pliniano configurou uma crítica anticapitalista e romântica, ruralista e regressiva, como e de que forma Buzaid reelaborara seu passado integralista nas matrizes fundamentais de seu ideário oficial no medicismo?

Como e de que maneira se reelaboram em plena guerra fria, no marco da doutrina de Segurança Nacional e Desenvolvimento, as lições integralistas que mobilizaram as concepções buzaidianas de ser humano, história, política, revolução, estado e direito? A dificuldade de análise advertida sinaliza que, no caso buzaidiano, o desafio está em compreender histórica e ideologicamente como e de que modo se articula a reapropriação feita pelo ministro da Justiça de Médici do velho ideário integralista pliniano no marco da ideologia da Segurança Nacional e Desenvolvimento. Como o jurista oficial do bonapartismo medicista, histórica e ideologicamente, "concilia” as novas matrizes da Ideologia 1964 com o velho integralismo pliniano? E de que forma as raízes ideológicas e/ou os pressupostos doutrinários integralistas, de vertente pliniana, informam o ideário bonapartista buzaidiano? Como fundem-se e readequam-se às concepções da guerra fria numa ditadura militar sob o signo da Segurança Nacional e Desenvolvimento?

\section{Conclusões}

Buzaid foi, na mais expressiva manifestação histórico-ideológica, um cruzado da guerra fria, um autêntico coldwarrior da extrema-direita brasileira. O professor de direito da FDUSP vinculou-se à linha-dura medicista do bonapartismo, e a sua rival castellista, que buscou construir o Brasil "grande potência" com "uma espécie de democracia regulada para a consolidação do capitalismo associado" (RAGO, 1998, p. 01), longe de ser 
uma ditabranda, optou pela "seletividade" no terrorismo planificado de estado para o cometimento de assassinatos políticas dos "inimigos" incriminados de subversivos (VALENTE; URIBE, 2018).

No caso em análise, o reacionário Buzaid foi um jurista-interlocutor admirado pela "Comunidade de Informações"10, projetando-se como um membro histórico e uma expressão ideológica de alto nível da facção ultra do bonapartismo de 1964. Segundo afirma o jurista Flávio Flores da Cunha Bierrenbach, o "Professor Buzaid, que foi ministro do Supremo Tribunal Federal, chegou a fazer até visita aos porões dos DOI-CODI" (BIERRENBACH apud SPILER; QUEIROZ, 2013, p. 275). Não foi apenas Gama e Silva, portanto, que se vinculou aos porões policiais e militares da ditadura.

Ao deixar o Ministério da Justiça de Médici, Buzaid internacionalizou como poucos sua cruzada anticomunista na América do Sul, destacando-se como um dos maiores cruzados anticomunistas da história brasileira ao integrar o "capítulo" brasileiro da Liga Mundial Anticomunista (WACL, na sigla em inglês). Antes de participar no biênio 1976-77 do Conselho Orientador do braço brasileiro wacliano, a Sociedade de Estudos Políticos, Econômicos e Sociais (SEPES), Buzaid já havia ajudado, ainda dentro do Ministério da Justiça ditatorial, na organização do $2^{\circ}$ Congresso da Confederação Anticomunista Latinoamericana (CAL), realizado no início de 1974 no Rio de Janeiro. Na mesma cidade, em abril de 1975, o ex-ministro seria o conferencista mais aplaudido na $8^{\mathrm{a}}$ Conferência da WACL. Segundo Fernando López, evidenciando as conexões entre a dictadura military brasileira e o complex WACL/CAL, "the Brazilian junta welcomed the cooperation and support provided by CAL and WACL. The governments of the States of Rio de Janeiro and São Paulo, for instance, hosted a number of CAL Conferences and other meeting during 1974 and 1975. Members of the regime, such as Admiral Faria Lima (governor of Rio de Janeiro) and ex Justice Minister Alfredo Buzai lent their support to, an actively participated in, WACL's VIII Congress in 1975” (LOPEZ, 2016, p. 300). Em 1977, Buzaid assistiria ao $3^{\circ}$ Congresso da CAL no Paraguai de Stroessner, que participou pessoalmente do conclave. A WACL, por meio da CAL, integrou as ações encobertas da Operação Condor antes, durante e depois da formalização, em 1975, desse

10 O Informe 209 de junho de 1975 do CIE, Estudo e apreciação sobre a revolução de 1964, criticando a autorreforma bonapartista geiseliana, aduzira que, "para o futuro, mas já se iniciando o estudo, dever-se-ia examinar a hipótese de transformar o Ato 5 numa prerrogativa de um poder moderador a ser instituído. Já o tivemos, durante o Império (...). Agora, seriam as FFAA, representadas pelo seu chefe, o presidente. Esta ideia tem sido proposta por juristas (prof. BUZAID, quando ministro; vice-governador MANUEL FERREIRA...) e também é nossa há muito tempo. (...) Com o poder moderador, o MDB não inquietaria, se vencesse eleições: exerceria cargos e funções sob a autoridade do Poder Moderador (BAFFA, 1989: 63) 
pacto criminoso forjado pelas ditaduras sul-americanas para a troca de informações e de prisioneiros capturados entre os países "condorenses"11.

Apesar (ou por causa) de seu papel de gestor nos crimes de estado e de lesa-humanidade cometidos pela ditadura militar recrudescida, Buzaid galgou pelas mãos do último general-ditador João Batista Figueiredo, em 1982, o cargo de ministro-magistrado no Supremo Tribunal Federal (STF). Sonho até hoje nutrido pelos ministros da Justiça brasileiros. Passando incólume apesar de sua ficha corrida de serviços prestados à gestão de estruturas repressivas de estado, a coroada carreira jurídica de Buzaid foi sempre exaltada por seus acólitos e, via de regra, pelo universo jurídico nacional. Insistem, até hoje, em cindir e separar a dimensão do "cientista" do direito - o que, a nosso juízo, é algo epistemologicamente impossível de sua atuação política no integralismo, na preparação do golpe de 1964 e, em especial, em sua gestão e ideologia oficiais no Ministério da Justiça Médici. Já se analisou nesta revista seu papel de gestor direto na ocultação de crimes de estado e de lesa-humanidade, quando se revisitou sua coordenação na Pasta da Justiça da feitura do Livro da verdade (ou Branco) ${ }^{12}$, a impublicável peça do desmentido oficial dos crimes da ditadura militar.

Aqui, finalmente, o que se pretendeu foi aportar uma compreensão histórica mais detida a respeito do ideário ultraconservador buzaidiano em sua própria imanência ideológica, demarcando sua gênese e apenas apontando a correspondente função social cumprida no bonapartismo medicista. Se toda contrarrevolução precisa de um teórico, Buzaid cumpriu à risca este papel: foi o ideólogo da contrarrevolução permanente e da perenização do bonapartismo de 1964. Se toda contrarrevolução precisa de um homem de ação, o jurista também cumpriu esta missão de modo intransigente: agiu com eficácia no trabalho de exercitar e legar politicamente a impunidade dos crimes da ditadura militar brasileira. Se toda contrarrevolução precisa de um jurista, Buzaid foi $o$ técnico em leis e em Direito capaz de coordenar e positivar as codificações do regime ditatorial de 1964. Buzaid sagrou-se, e não é pouco, como o jurista ditatorial.

O entendimento sobre as raízes ideológicas do ultraconservadorismo buzaidiano, enfim, propôs-se aqui como uma parte apenas do gigantesco quebra-cabeça que foi (e continua sendo) a história de longa duração e persistência das linhagens ideológicas mais virulentas

${ }^{11} \mathrm{Na}$ síntese de López, por conseguinte, "the civilian partners linked to CAL and WACL and their Anticommunist counteroffensive created the conditions and became the feathers that allowed Condor to fly high and far beyond South America to the U.S. and Europe, murdering opponents so as to shock the exiles and disrupt the solidarity campaigns" (LÓPEZ, 2916: 322).

${ }_{12} \mathrm{O}$ Livro foi descoberto pelo historiador Carlos Fico nos arquivos da extinta Divisão de Segurança e Informações do Ministério da Justiça (cf. FICO, 2001). 
da autocracia burguesa brasileira. Esta é o ventre, que segue frutificando, dos projetos mais bestialmente antipopulares deste país. Bertolt Brecht, a respeito da emersão da extrema-direita como "saída" imposta pela crise do capital, circunscreveu no capitalismo o fecundo ventre reprodutor da besta nazifascista. A autocracia burguesa brasileira representa a usina ontosocietária de ideias que matriza a reprodução da ideologia ultraconservadora nacional. Persistindo conjuntamente a autocracia burguesa e o ultraconservadorismo, somente dessa forma poderão ser superados. Daí a importância e a urgência do estudo e compreensão históricas do fenômeno ideológico ultraconservador brasileiro. Os Neobuzaids, na dicção da cartunista Laerte Coutinho, que revela a enraizada permanência buzaidiana na sociedade brasileira atual, configuram uma nova/velha extrema-direita que, honrando torturadores, empoleira-se nos bustos de ditadores e generais. É preciso (re)conhecer esta história para transformá-la.

Figura 1
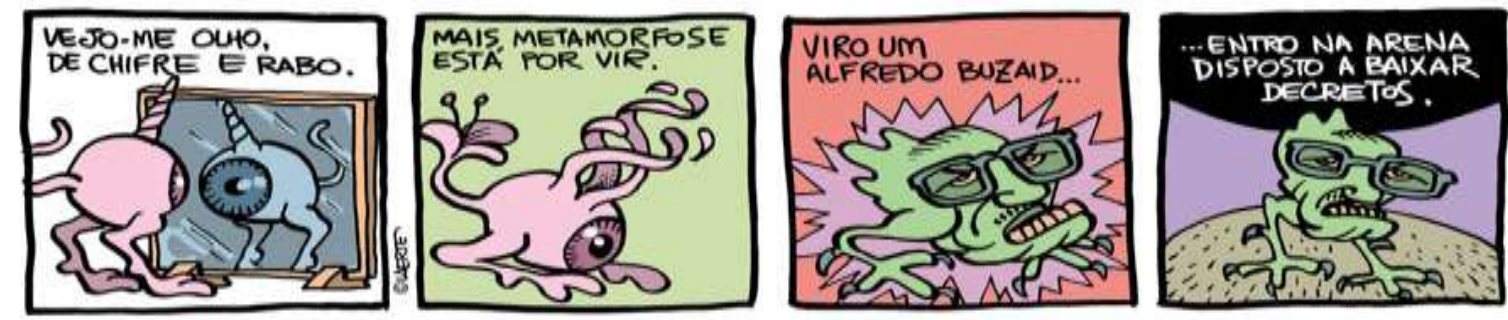

Fonte: Laerte (2013).

Figura 22
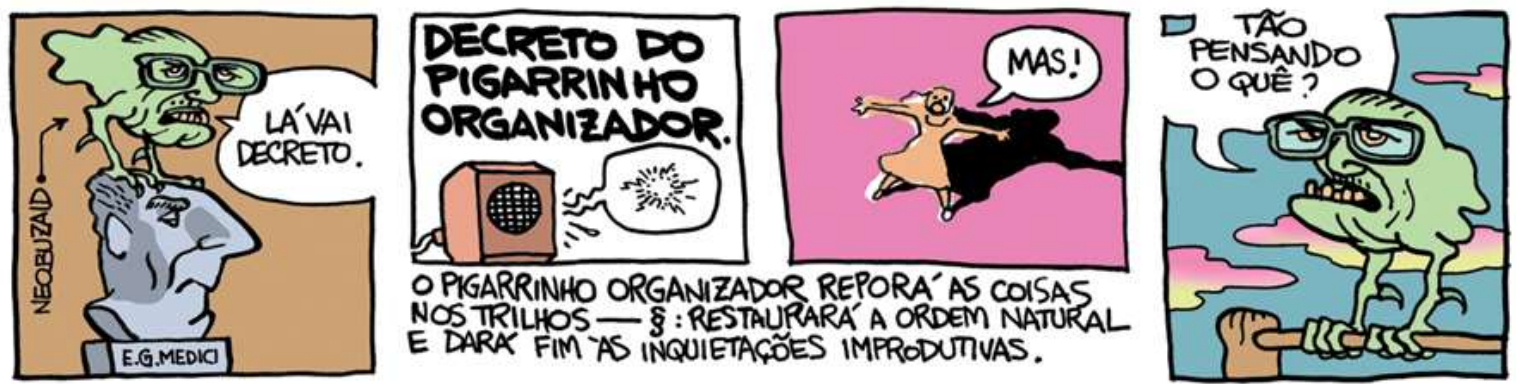

Fonte: Laerte (2013). 


\section{Referências bibliográficas}

ASSUNÇÃO, Vânia Noeli Ferreira de. Ditadura como bonapartismo: apreensões marxistas sobre o regime inaugurado em 1964. Verinotio Revista on-line de Filosofia e Ciências Humanas, n. 17, Ano IX, abr./2013. BUZAID, Alfredo. A missão da Faculdade de Direito na conjuntura política atual. (Estudo sobre os rumos da democracia no Brasil) [1966]. Revista da Faculdade de Direito da Universidade de São Paulo, v. LXIII, 1968.

- Jubilação sem júbilo. Revista da Faculdade de Direito da Universidade de São Paulo, v. LXIV, 1969.

. Rumos políticos da revolução brasileira. Brasília: Departamento de Imprensa Nacional, 1970a.

- Marxismo e cristianismo (o problema do ateísmo). Brasília: Departamento de Imprensa Nacional, 1970b.

- Em defesa da moral e dos bons costumes. Brasília:

Departamento de Imprensa Nacional, 1970c.

- O estado federal brasileiro. Brasília: Departamento de Imprensa Nacional, $1970 d$.

- A renovação da ordem jurídica positiva. Brasília: Departamento de Imprensa Nacional, 1971.

- Da conjuntura política nacional. Brasília: Departamento de Imprensa Nacional, 1972.

- Humanismo político. Brasília: Departamento de Imprensa Nacional, 1973.

. Dom Pedro II [1975]. Revista da Academia Paulista de Letras, ano XXIV, n. 90, maio, 1977.

. Rui e a questão social [1965]. In: Ensaios literários e históricos. São Paulo: Editora Saraiva, 1983.

CASTELLO BRANCO, Carlos. Os militares no poder. O baile das solteironas v. III. Rio de Janeiro: Nova Fronteira, 1979.

- Decisões que desestabilizam. Coluna do Castello. Jornal do Brasil, $1^{\circ}$ Caderno, 5 jul. 1987.

CHASIN, J. O integralismo de Plínio Salgado: forma de regressividade no capitalismo híper-tardio. São Paulo: Ciências Humanas, 1978.

DREIFUSS, René Armand. 1964: A conquista do estado. Ação política, poder e golpe de classe. Petrópolis: Vozes, 1981.

FICO, Carlos. Como eles agiam. Rio de Janeiro: Record, 2001.

LAERTE. Cartuns. Folha de S. Paulo, 11 e 12 maio 2013.

LÓPEZ, Fernando. The feathers of condor. Transnational state terrorism, exiles and civilian anticommunist in South America. Reino Unido: Cambridge Scholars Publishing, 2016. 
MACHADO, Rodolfo Costa. Alfredo Buzaid e a contrarrevolução burguesa de 1964: Crítica histórico-imanente da ideologia bonapartista do direito, da política e do estado de Justiça. Dissertação (Mestrado) apresentada à Pontifícia Universidade Católica de São Paulo (PUC-SP), São Paulo, 2015.

PEDREIRA, Fernando. Brasil Política. 1964-1975. São Paulo: Difel, 1975. RAGO, Maria Aparecida de Paula. José Ermírio de Moraes: A trajetória de um empresário nacional. São Paulo: Paz e Terra, 2008.

RAGO FILHO, Antonio. A ideologia 1964: os gestores do capital atrófico. Tese (Doutorado) defendida na Pontifícia Universidade Católica de São Paulo (PUC-SP), São Paulo, 1998.

- Sob este signo vencerás! A estrutura ideológica da autocracia burguesa bonapartista. Cadernos AEL (Arquivo Edgard Leuenroth IFCH/Unicamp), Campinas, v. 14/15, 2001.

REALE, Miguel. Revolução e normalidade constitucional. In: A Revolução de 31 de Março. $2^{\circ}$ aniversário. Rio de Janeiro: Biblioteca do Exército, 1966.

- Problemas institucionais do estado contemporâneo. Curso Superior de Guerra. Rio de Janeiro: Escola Superior de Guerra, 18 maio 1972.

SPIELER, Paula; QUEIROZ, Rafael Mafei Rabelo (Coord.). PAYAR, André Javier Ferreira et al. Advocacia em tempos dificeis: Ditadura Militar (1964-1985). Curitiba/Rio de Janeiro/São Paulo: Projeto Marcas da Memória (Comissão de Anistia/Ministério da Justiça)/FGV-Direito, 2013. VALENTE, Rubens; URIBE, Gustavo. Chefe da CIA disse que Geisel assumiu controle sobre execuções sumárias na ditadura. Folha de S. Paulo, 10 maio 2018.

VEJA. Edição 188, 12 abr. 1972.

Como citar:

MACHADO, Rodolfo Costa. Contrarrevolução permanente, antiliberalismo e anticomunismo: as raízes ideológicas do bonapartismo de Alfredo Buzaid, o jurista ditatorial (1965-1974). Verinotio - Revista online de Filosofia e Ciências Humanas, Rio das Ostras, v. 25, n. 2, pp. 287330, nov. 2019.

Data do envio: 25 jun. 2019

Data do aceite: 07 out. 2019 